\section{Trakya Eğitim Dergisi}

Cilt 10, Sayı 1

Ocak 2020, 1-22

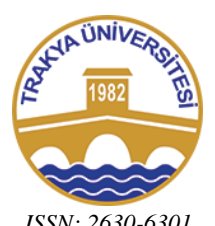

ISSN: $2630-6301$

Doi:10.24315/tred.537847

Araşttrma Makalesi
Trakya Journal of Education

Volume 10, Issue 1

January 2020, 1-22

Yayına Kabul Tarihi:12.02.2020.

Research Article

\title{
Sınıf Öğretmenlerinin Özel Gereksinimli Öğrencilerin Eğitimine Yönelik Görüşlerinin İncelenmesi
}

\section{Investigation of Classroom Teachers' Views on Education of Children with Special Needs}

\section{Taner ALTUN ${ }^{1}$, Tunahan FILIZ ${ }^{2}$}

\begin{abstract}
ÖZ: Bu araştırmada, sınıfında özel gereksinimli öğrenci bulunan sınıf öğretmenlerinin öğrenme-öğretme sürecinde yaptıkları uygulamalar ve karşılaştıkları güçlüklerin incelenmesi amaçlanmıştır. Araştırma nitel araştırma yöntemlerinden durum çalışması çerçevesinde şekillendirilmiş olup, verilerin toplanmasında hazırlanan yarı yapılandırılmış görüşme formalarından yararlanılmıştır. Amaçlı örnekleme yöntemlerinden olan kolay ulaşılabilir örnekleme yoluyla ulaşılabilen sınıfında özel gereksinimli öğrenci bulunan 10 sınıf öğretmeni ile çalışma yürütülmüştür. Veriler yarı-yapılandırılmış görüşme tekniğiyle elde edilmiștir. Bu veriler içerik analizine tabi tutularak çözümlenmiştir. Veri analizi sürecinde NVivo 9.0 programından yararlanılmıştır. Yapılan araştırma sonucunda, elde edilen sonuçlara göre öğretmenlerin özel gereksinimli öğrencilerle ilgili bilgi düzeylerinin yetersiz, ilgili konuda veliöğretmen işbirliğinin zayıf ve öğretmenlerin bu güçlüklere çözüm getirme noktasında yeterli desteği alamadıkları tespit edilmiştir. Ayrıca sınıf öğretmenlerinin bu öğrencileri belirleyebildikleri, aileleriyle gerekli iletişimi kurduğu ve bu çocukların sosyal ortamlarda desteklenmesi ve akranları tarafindan kabulü için çalışmalar yaptığı tespit edilmiştir. Bununla birlikte sınıf öğretmenlerinin öğrenme-öğretme sürecinde öğretimin bireyselleştirilmesi anlamında öğretim sürecinde bir takım uygulamalar yaptıkları, uygulamalarda bazı sorunlarla karşılaştığı ve bu sorunların üstesinden gelebilmek için destek aldığı da ifade edilmiştir. Çalışmanın sonunda sınıf öğretmenlerinin özel gereksinimli çocuklara daha kaliteli eğitim vermelerine yönelik çeşitli öneriler sunulmuştur.
\end{abstract}

Anahtar sözcükler: Sınıf öğretmeni, özel gereksinimli çocuklar, nitel araştırma

\section{Cite this article as:}

Altun, T. \& Filiz, T. (2020). Investigation of classroom teachers' views on education of children with special needs. Trakya Eğitim Dergisi, 10(1), 1-22.

\section{Introduction}

\section{EXTENDED ABSTRACT}

Children with special needs are children whose physical characteristics and/or learning abilities differ considerably from the norm (Akçamete, 2012). In another definition, children who need special education are expressed as children who exhibit different behaviors from their peers and who are determined to require different education needs by individualized education programs (Eripek, 2005). It is possible for students with special needs to be self-sufficient as independent and productive individuals in social environments and to determine their educational needs by providing them with appropriate educational environments and services (Şahbaz and Kalay, 2010).

\footnotetext{
${ }^{1}$ Doç. Dr., Trabzon Üniversitesi, e-posta: taneraltun@ gmail.com, ORCID ID: 0000-0001-9946-7257

2 Öğr. Gör., Bayburt Üniversitesi, e-posta: tunahanfiliz@gmail.com, ORCID ID: 0000-0002-3149-8783
}

Keywords: Classroom teacher, children with special needs, qualitative research 
When the studies conducted in this area are examined, it is seen that the studies focus on mainstreaming practices and attitudes of teachers towards students with special needs. In addition, the adaptations of teachers in the teaching and learning process were emphasized in order to individualize teaching. In the studies conducted, it was determined that teachers made adaptations such as using different materials in the learning-teaching process, giving homework by involving the family in the case, making appropriate activities and exercises to the level of the student. However, no research has been found on the practices of classroom teachers to students with special needs in the learning-teaching process and the difficulties encountered in these practices. With the training of students with special needs in the general education classes together with their peers, the practices that the classroom teachers need to do in the learning-teaching process have started to gain importance. Considering all these situations, what kind of practices the classroom teachers carry out in the learning-teaching process, what kind of difficulties they encounter in this process and whom they get support from are the subjects that should be emphasized. This research differs from other studies in this respect. In addition, it is expected that this study will guide the classroom teachers, who have students with special needs in their classroom, in terms of the practices to be done in the learning-teaching process and accordingly guide the other studies to be done.

\section{Method}

This research was designed as case study within the qualitative research approaches. These kinds of studies aim to describe an existing subject in natural conditions and within the framework of certain criteria. For this purpose, case study method was used in this study because it was aimed to determine the practices, carried out in the teaching-learning process, and difficulties of the classroom teachers who have students with special needs in their classroom. Semi-structured interview technique was used in the data collection process. First, semi-structured interview questions were prepared, and the interview questions were revised by taking expert opinion and pilot application was conducted with one of the classroom teachers to participate in the interview. The sample of the research consists of 10 classroom teachers, which can be reached through convenient sampling that is one of the purposive sampling methods. The research was conducted in the fall semester of 2018-2019 academic year with the classroom teachers working in various schools in Bayburt province and having special needs in their classrooms. During the interviews, the tape recorder was used and the teachers' opinions were also recorded by taking notes. The recorded data were then turned into plain text and the findings were presented with various images (tables, graphs, figures, etc.). The collected data were summarized and interpreted by the descriptive analysis method and analyzed in depth with the content analysis method. Nvivo9.0 software was used in the analysis process.

\section{Result and Discussion}

In the light of the findings of the research, it was concluded that the classroom teachers' educational quality were insufficient for students with special needs. The teachers stated that they did not receive any training for students with special needs at the university and those who received the trainings specified that these trainings were far from meeting the needs. In addition, it was found that classroom teachers received in-service training for students with special needs but these trainings were also insufficient.

When the research findings were examined, the characteristics of the students with special needs were determined by the eyes of the classroom teachers. Classroom teachers emphasized that students with special needs learned late and with difficulty, had low academic achievement compared to their peers, had difficulty in reading, had difficulty in writing and mathematics skills, had difficulty in perception, had low communication skills, had low self-confidence and got tired fast.

To determine these students, teachers benefit from their observations, from the student's academic success, from the student's family and the school counselor, from various tests, from the student's level of perception and undesirable behaviors, and from the comparison with friends. In addition, classroom teachers do the following for supporting students with special needs in social settings and for peer acceptance: to give the student a sense of accomplishment through the ability of the student, to give the students the responsibilities they can do, and to explain the student's situation to their peers, to organize games that they can play with their peers, to encourage students and not to separate them from other students and finally to conduct group works. 
Another result of the study is that the teachers informed the families of the students with special needs but the parents were reactive to the situation in the first place. However, it was determined that the parents accepted the situation in time and the teachers became more in contact with the parents and accordingly the cooperation increased. In this process, the cooperation between the teacher and the parents could be made partially.

It was concluded that the classroom teachers, who have students with special needs in their classrooms, organized different practices for students in the learning-teaching process. It was concluded that to create an effective and efficient learning-teaching process, classroom teachers made smart board applications for students with special needs, organized activities parallel to those carried out in the support training room, organized activities in line with the prepared Individualized Education Program, did one-to-one training, used remarkable visual materials, used the technique of dramatization (gamification) frequently in lessons and made concretization.

It was concluded that the classroom teachers encountered some problems in the practices made during the learning-teaching process. Teachers listed these problems as follows: Parental disinterest, lack of time, undesirable behaviors, students closing themselves to communication, distracting and getting bored fast, the inadequacy of students with special needs and other students preventing them from learning.

The following suggestions can be offered in line with these results: Trainings can be organized for classroom teachers, parents and those concerned about the students with special needs. Regulations can be made in the content of the courses that the classroom teachers receive towards the students with special needs in the undergraduate education, and furthermore, it is possible to carry out practical studies rather than theory. Classroom teachers can be given detailed information about the types of inability to identify students with special needs. In addition, defining characteristics of the types of inability can be given to teachers in brochures. It can be ensured that there is a school counselor in all primary schools where there are students with special needs. The support training room can be arranged and maintained in a way to support the learning-teaching process. In addition, a separate room for support training rooms can be arranged in schools, necessary equipment can be provided.

\section{GİRIŞ}

Özel gereksinimli çocuklar, bedensel özellikleri ve/veya öğrenme yetenekleri normdan oldukça farklılaşan çocuklardır (Akçamete, 2012). Başka bir tanımda özel eğitime gereksinim duyan çocuklar, akranlarından farklı davranışlar sergileyen, farklı eğitim ihtiyaçları bireyselleştirilmiş eğitim programlariyla belirlenen çocuklar olarak ifade edilmektedir (Eripek, 2005). Özel gereksinimi olan çocuklar kavramı sadece yetersizliği olan çocuklar için değil aynı zamanda performansı üst seviyede olan bireyler için de kullanılmaktadır. Özel gereksinimi olan çocuklar terimi bu anlamda kapsayıcı bir terim olarak karşımıza çıkmaktadır. Öğrenme ve/veya davranış problemleri olan, duygusal bozukluğu ya da fiziksel yetersizliği olan ve zihinsel olarak üstün ya da özel yetenekli çocuklar bu gruba girmektedir (Akçamete, 2012). Ülkemizde 1997 yılında çıkarılan 573 sayılı Özel Eğitim Hakkında Kanun Hükmünde Kararname' de özel eğitim gerektiren birey kavramı bütünleştirici bir kavram olarak kullanılmakta olup, bireysel özellikleri ve akademik yeterlilikleri bakımından çeşitli nedenlerden dolayı akranlarından normalden anlamlı farklılık gösteren birey olarak ifade edilmektedir.

Özel gereksinimli öğrencilerin sosyal ortamlarda bağımsız ve üretken bireyler olarak kendi kendine yetebilmeleri, eğitim ihtiyaçlarının tespit edilmesi, ihtiyaç duyduğu uygun eğitim ortamlarının ve hizmetlerin kendilerine sunulmasıyla mümkün olmaktadır (Şahbaz \& Kalay, 2010). Özel gereksinimli öğrencilerin belirlenen ihtiyaçları doğrultusunda eğitim ihtiyaçlarının karşılanması için çeşitli eğitim ortamları bulunmaktadır. Özel eğitim okulları, normal okullarda bulunan özel eğitim sinıfları ve normal sinıflar bu ortamlardan bazılarıdır (İlgar, 2017; Batu, Kırcaali-İftar \& Uzuner, 2004). Son yıllarda özel eğitim hizmetlerinin anlamında değişiklik göze çarpmaktadır. Özel eğitim denildiğinde sadece özel gereksinimleri olan çocukların yetersizliklerine uygun ortamlarda eğitim vermek algılanmıyor, aynı zamanda onların özel eğitim gereksinimlerini karşılayacak en uygun ortamlarda eğitim vermek ve onları en az kısıtlayıcı ortamlarda eğitmek olarak algılanmaktadır (Diken, 2015; Akçamete, 2012). En az kısıtlayıcı eğitim ortamı, bir öğrencinin akranlarıyla en fazla birlikte 
olabileceği ve eğitim gereksinimlerinin eksiksiz bir şekilde karş1lanması ayrıca öğrencinin en üst düzeyde başarı göstereceği ortam olarak ifade edilmektedir (Eripek, 2005; Batu \& Kırcaali-İftar, 2005).

Özel gereksinimli olan öğrenciler, davranış özellikleri ve öğrenme bakımından akranlarından önemli derecede farklılıklar gösterirler. Bu konuda bazı öğrenciler hafif düzeyde yetersizlikler gösterirken, bazı öğrenciler ise ileri düzeyde yetersizlikler gösterebilmektedir (Akçamete, 2012). Yetersizlik gösteren tüm öğrenciler, öğrenme ve öğretme sürecinden diğer tüm öğrenciler gibi en iyi şekilde yararlanmak isterler. Yapılan çalışmalar incelendiğinde, araştırmaların büyük bir çoğunluğunda, akranlarıyla genel eğitim sınıflarında bir arada eğitim gören özel gereksinimli öğrencilerin akademik gelişimlerinin özel gereksinimli öğrencilerle birlikte özel eğitim sınıflarında eğitim gören öğrencilerden daha hızlı olduğu belirtilmektedir (Freeman \& Alkin, 2000). Öğretim, özel gereksinimli öğrenciler için bireyselleştirildiğinde ya da bireyselleştirilmiş eğitim programı hazırlandığında, özel gereksinimi olan öğrencinin öğrenmesi etkili ve verimli olabilmektedir (Kırcaaliİftar, 1998).

Öğretimin bireyselleştirilmesi ve yetersizliği olan öğrencinin akranlarıyla birlikte en az kısıtlayıcı ortam olan genel eğitim sınıflarında eğitilmesi meselesi ortaya kaynaştırma uygulamalarını çıkarmaktadır. Öğrenme-öğretme sürecinde özel gereksinimli öğrencinin sınıfta kaynaştırılması ve bireysel eğitim programının düzenlenmesi öğrencilerin gelişimi açısından önemli görülebilir. Sınıf ortamında etkili bir öğrenme-öğretme süreci kaynaştırma uygulamalarının başarısına bağlıdır. Kaynaştırma, özel gereksinimli öğrencilerin genel eğitim sınıflarında akranlarıyla birlikte, hem sınıf öğretmenine hem de özel gereksinimli öğrenciye ihtiyaçları doğrultusunda destek özel eğitim hizmetleri sağlanarak eğitilmesi olarak ifade edilmektedir (Kırcaali-İftar, 1998). Özel Eğitim Hizmetleri Yönetmeliği'nde kaynaştırma eğitimi; "özel eğitim ihtiyacı olan bireylerin her tür ve kademede diğer bireylerle karşılıklı etkileşim içinde bulunmalarını ve eğitim amaçlarını en üst dizeyde gerçekleştirmelerini sağlamak amacıyla bu bireylere destek eğitim hizmetleri de sunularak akranlarıyla birlikte tam zamanlı ya da özel eğitim sınıflarında yarı zamanlı olarak verilen eğitim" şeklinde ifade edilmektedir (Resmi Gazete, 2018). Yapılan tanımların bazılarında, kaynaştırma eğitiminin sadece özel eğitim ihtiyacı olan bireyleri için olmadığı aynı zamanda tüm öğrencileri toplumun birer parçası olabilmesi için akademik ve sosyal olarak desteklenmesi anlayışına dayanan akademik ve sosyal alanlarda destekleyerek, toplumun birer parçası olma olanağı sunan bütüncül bir eğitim olduğu da ifade edilmiştir (Sucuoğlu, 2006).

Kaynaştırma uygulamalarının başarılı olabilmesi, okul yönetimi, öğretmenler, anne-babalar, yetersizliği olmayan bireyler ve özel gereksinimli bireylerin işbirliği içerisinde sürece dâhil olmalarıyla sağlanabilir (Batu, 2000). Ayrıca özel gereksinimli öğrencinin toplumsal ve sosyal kabulü, ihtiyaçlarının belirlenmesi ve önemsenmesi, öğrenciye bireyselleştirilmiş eğitim programı sunulması, öğretmenin personel ve velilerle işbirliği içinde çalışması, öğrenciye sınıfın dışında destek hizmetlerinin sağlanması kaynaştırma uygulamasının başarıya ulaşabilmesi açısından önemli öğeler olarak sayılabilir (Özokçu, 2013; Batu, 2015). Öğretmene ve öğrenciye sağlanması gereken destek hizmetleri ise öğrenme-öğretme ortamının fiziksel olarak öğrenci ihtiyaçlarına uygun şekillendirilmesi, program hedeflerinin, kullanılacak öğretim materyallerinin ve öğretim yöntemlerinin belirlenmesi gibi çeşitli düzenlemeleri kapsamaktadır (Kargın ve diğ., 2010).

Kaynaştırma eğitimlerinin yaygınlaşmasıyla birlikte okullar ve sınıflar, hiçbir çocuğun geride kalmayacă̆ı, tüm öğrencileri kapsayacak, öğrencilerin bireysel ihtiyaçlarına cevap verecek şekilde düzenlenmektedir. $\mathrm{Bu}$ düzenleme, tüm öğrencilerin öğrenmeleri sağlayacak düzenlemelerin yapılmasını gerekli kılmaktadır (Rosenberg ve diğerleri, 2008). Eğitim ve öğretimin öğrenciler için bireyselleştirilmesini içeren öğretimsel uyarlamalar farklı temalarda olmakla birlikte ana temalar; fiziksel düzenlemeler, sınıf iklimine yönelik düzenlemeler, sürece ilişkin düzenlemeler, öğretimsel düzenlemeler ve işleyişe ilişkin düzenlemeler şeklinde sıralanmaktadır (Smith ve diğerleri, 2008).

Öğrenme-öğretme sürecinde yapılan öğretimsel düzenlemeler, öğrencinin bireyselleştirilmiş eğitim programı doğrultusunda oluşturulan hedef kazanımları gerçekleştirebilmesi için kazanımlara ve öğrenci seviyelerine göre farklı öğretim stratejilerinin kullanılmasını içermektedir (Kargın ve diğerleri, 2010). Öğretmenler tarafindan bu tür farklı öğretim yöntemlerinin kullanılması özel gereksinimli öğrencilerin öğrenmesini kolaylaştıracağı gibi diğer öğrenciler için etkili öğrenmeyi sağlayacaktır (Akçamete, 2012). Sınıf ortamında kullanılabilecek farklı öğretim yöntemleri arasında, anlatıma dayalı 
doğrudan öğretim, keşfetmeye dayalı buluş yoluyla öğrenme ve işbirliği içinde öğrenme bulunmaktadır (Sucuoğlu \& Kargin, 2006; Olson \& Platt, 2004).

Literatür incelendiğinde sınıfinda özel gereksinimli öğrenci bulunan öğretmenlerin öğrenmeöğretme sürecinde karşılaştıkları sorunlara yönelik olarak farklı amaçlarla yapılan pek çok araştırma bulunmaktadır. $\mathrm{Bu}$ araştırmalarda genelde öğretmenlerin kaynaştırma ve BEP uygulamasında karşılaştıkları güçlüklerin üzerinde durmuşlardır. Öğretmenlerinin kaynaştırma uygulamalarında, hem hizmet öncesi hem de hizmet içinde gerekli eğitimleri almadıkları ve kendilerini kaynaştırma uygulamalarında yeterli görmedikleri (Demir \& Açar, 2011; Babaoğlan \& Y1lmaz, 2010) üzerinde durulmaktadır. Öğretmenlerin öğrenme öğretme sürecinde kaynaştırma eğitimine yeterli zaman ayıramadıkları (Saraç \& Çolak, 2012), zaman ayırabilen öğretmenlerin ise materyal ve fiziki ortamı yetersiz buldukları (Erişkin, Kıraç, \& Ertuğrul, 2012; Shevlin, Winter, \& Flynn, 2013) tespit edilmiştir. Ayrıca öğretmenlerin, kaynaştırma uygulamalarının öğrenme-öğretme sürecinde etkili bir şekilde uygulanması için oluşturulan BEP (bireyselleştirilmiş eğitim planı) hakkında yeterli bilgiye sahip olmadıkları ve uygulama noktasında zorluklarla karşılaştıkları (Avcıoğlu, 2011) göze çarpmaktadır.

Öğretmenlerin öğrenme-öğretme sürecinde yapmış oldukları uyarlamalar ve sınıf yönetimiyle ilgili yapılan çalışmalar, öğretmenlerin ders sürecinde farklı materyal kullanma, aileyi de işin içine katarak ödev verme, gereksinimi olan öğrencinin seviyesine uygun etkinlikler ve alıştırmalar yaptırma gibi uyarlamalar yaptıkları ancak bu uyarlamaları daha etkili ve verimli yapabilmek için bilgilendirmeye ihtiyaç duydukları tespit edilmiştir (Sadioğlu, 2011). Yapılan bir diğer çalışmada ise bu çalışmaya paralel olarak sınıfında özel gereksinimli öğrenci bulunan öğretmenlerin, bazı düzenlemelere gittiği, öğretim materyallerini öğrenci özelliklerine göre şekillendirdiği, etkili öğretim yöntemlerini kullandığını bu uygulamalarında diğer öğrencilerin gelişimlerini de olumlu yönde etkilediği üzerinde durulmuştur (İlgar, 2017).

Sonuç olarak, özel gereksinimli öğrencilerin akranlarıyla birlikte genel eğitim sınıflarında eğitim alabilmeleri için sınıf öğretmenlerine büyük görevler düşmektedir. Sınıf öğretmenlerinin özel gereksinimli öğrenciler hakkındaki bilgi düzeyinin ne olduğu, öğrenme-öğretme sürecinde ne tür uygulamalar yaptıkları, bu uygulamaların niteliklerinin neler olduğu, uygulamalarda ne tür güçlüklerle karşılaştıkları üzerinde önemle durulması gereken bir konudur. Çünkü özel gereksinimli öğrencilerin sınıf öğretmeni ya da aileleri tarafından erken fark edilmesi eğitimin bireysel ihtiyaçları doğrultusunda şekillendirilmesine olanak tanıyacaktır. Ayrıca bu çocuklar ilkokulda sınıf ortamında kendilerini açık seçik ifade etme olanağ 1 bulabilirler. Geçmiş çalışmalarda da belirtildiği gibi özel gereksinimli öğrencilerin erken tanı alması eğitimleri ve sosyal hayatları açısından oldukça önemlidir.

Yapılan çalışmalar incelendiğinde, araştırmaların kaynaştırma uygulamaları ve öğretmenlerin özel gereksinimli öğrencilere yönelik tutumları üzerine odaklandığı görülmektedir. Ancak öğrenmeöğretme sürecinde sınıf öğretmenlerinin özel gereksinimli öğrencilere yönelik yapmış oldukları uygulamaların neler olduğu ve bu uygulamalarda karşılaşılan güçlükler üzerine herhangi bir araştırmaya rastlanılmamıştır. Özel gereksinimli öğrencilerin akranlarıyla birlikte genel eğitim sınıflarında eğitilmesinin önem kazanmasıyla birlikte öğrenme-öğretme sürecinde sınıf öğretmenlerinin yapması gereken uygulamalar önem kazanmaya başlamıştır. Tüm bu durumlar dikkate alındığında bu araştırmada sınıf öğretmenlerinin öğrenme-öğretme sürecinde ne tür uygulamalar yaptıkları, bu süreçte ne tür zorluklarla karşılaşııkları ve kimlerden destek aldıkları üzerinde durulması gereken konulardır. Araştırma bu yönüyle diğer çalışmalardan ayrılmaktadır. Ayrıca bu çalışmanın sınıfında özel gereksinimli öğrenci olan sınıf öğretmenlerine öğrenme-öğretme sürecinde yapılacak olan uygulamalarla ilgili rehber olması, yapılacak çalışmalara yol göstermesi beklenmektedir.

$\mathrm{Bu}$ araştırmada, sınıfında özel gereksinimli öğrenci bulunan sınıf öğretmenlerinin öğrenmeöğretme sürecinde yaptıkları uygulamalar ve karşılaştıkları güçlüklerin incelenmesi amaçlanmıştır. Araştırmada ayrıca aşağıdaki sorulara cevaplar aranmaktadır:

1. Sınıf öğretmenlerinin algılarına göre özel gereksinimli çocukların eğitimine yönelik yeterlikleri ne düzeydedir?

2. Sınıf öğretmenleri akranlarından farklı gereksinimleri olan öğrencilerin belirlenmesi ve eğitimlerine yönelik ne tür faaliyetler yapmaktadır?

3. Sınıf öğretmenlerinin öğrenme-öğretme sürecinde özel gereksinimli öğrencilere yönelik yapmış oldukları uygulamalar, karşılaştıkları sorunlar ve aldıkları destekler nelerdir? 


\section{YÖNTEM}

$\mathrm{Bu}$ araştırma, nitel araştırma yaklaşımlarından özel durum çalışması olarak desenlenmiştir. Bu tür araştırmalar, var olan bir konuyu doğal koşullarda ve belirli kriterler çerçevesinde ayrıntılı bir şekilde betimlemeyi amaçlar (Çepni, 2012). Bu amaç doğrultusunda bu araştırmada, sınıfında özel gereksinimli öğrenci bulunan sınıf öğretmenlerinin öğrenme-öğretme sürecinde yapmış oldukları uygulamalar ve karşılaştıkları güçlüklerin belirlenmesi amaçlandığı için özel durum çalışması kullanılmıştır. Bu yöntemde kendine özgü bir durumun bütüncül bir şekilde ifade edilmesi söz konusu olmaktadır (Yıldırım \& Şimşek, 2016). Yapılan bu araştırmada, sınıfında özel gereksinimli öğrenci bulunan sınıf öğretmenlerinin görüssleri doğrultusunda, öğrenme-öğretme sürecinde yapılan uygulamalar ve karşılaşılan güçlükler çeşitli boyutlarıyla incelenmiştir. Tek bir durum içerisinde çoğu kez birden fazla alt tabaka veya birim olabilir. Bu durumda birden fazla analiz birimini içeren "iç içe geçmiş tek durum" türü kullanılır (Yıldırım \& Şimşek, 2016). Bu araştırmada sınıfında özel gereksinimli öğrenci bulunan sınıf öğretmenlerinin öğrenme-öğretme sürecinde yaptıkları uygulamalar ve karşılaştıkları güçlükler iç içe geçmiş tek durum olarak incelenmiştir. Analizlerin kolay olması, görüşme yapılan kişiye kendini ifade etme imkânı, gerektiğinde derinlemesine bilgi sağlama gibi avantajları (Büyüköztürk ve diğerleri, 2017) nedeniyle böyle bir durumun incelenebilmesi için yarı yapılandırılmış görüşme tekniğinden yararlanılmıştır. Yarı yapılandırılmış görüşme esnek soruların kullanılabildiği, birincil düzeyde bilgi sağlayan nitel veri toplama aracıdır (Çepni, 2012; Ekiz, 2013).Görüşme sorularında esnek sorulara yer verilerek verilerin niteliği ve derinliği artırılmıştır.

\section{1. Çalışma Grubu}

Araştırmada görüşlerine başvurulan örneklem grubunu, 2018-2019 eğitim öğretim yılında Bayburt il merkezinde görev yapmakta olan ve amaçlı örnekleme yöntemlerinden biri olan kolay ulaşılabilir örneklemeyle belirlenen 10 sınıf öğretmeni oluşturmaktadır. Kolay ulaşılabilir durum örneklemesi nitel araştırmalarda yaygın kullanılan bir örnekleme yöntemi olmakla beraber bu yöntem araştırmaya hız ve pratiklik kazandırır (Yıldırım \& Şimşek, 2016).

Araştırma kapsamında, sınıfında özel gereksinimli öğrenci bulunan sınıf öğretmenlerine yönelik hazırlanmış olan yarı yapılandırılmış görüşme formunun ilk bölümünde, öğretmenlerin hizmet yılı, cinsiyetleri, yaşı, okutmuş oldukları sınıf düzeyi, mezuniyet durumları, mezun olunan üniversite ve özel gereksinimli öğrencilere yönelik hizmet içi eğitim alma durumları ile ilgili sorular sorulmuştur. Öğretmenlerle ilgili elde edilen ön bilgiler araştırma açısından önemlidir. Edinilen ön bilgiler, elde edilecek veriler ve yapılacak olan yorumlarda yol gösterici olacaktır. Ayrıca edinilen bu bilgiler araştırmanın güvenirlik seviyesine de katkı sağlayacaktır. Tablo 1'de araştırmada görüşlerinden faydalanılan sınıf öğretmenleriyle ilgili ön bilgiler sunulmaktadır.

Tablo 1. Araştırmada görüşleri alınan sınıf öğretmenleriyle ilgili ön bilgiler

\begin{tabular}{|c|c|c|c|c|c|c|c|}
\hline Kod & $\begin{array}{c}\text { Hizmet } \\
\text { Yılı }\end{array}$ & Cinsiyet & Yaş & $\begin{array}{c}\text { Sınıf } \\
\text { Düzeyi }\end{array}$ & $\begin{array}{c}\text { Mezuniyet } \\
\text { Durumu }\end{array}$ & $\begin{array}{l}\text { Mezun } \\
\text { Olunan } \\
\text { Üniversite }\end{array}$ & $\begin{array}{c}\text { Özel Gereksinimli Öğrencilere } \\
\text { Yönelik Hizmet İçi Eğitim Alma } \\
\text { Durumu }\end{array}$ \\
\hline Ö1 & 6 & $\mathrm{~K}$ & 28 & 2 & Lisans & $\begin{array}{l}\text { Eğitim } \\
\text { Fakültesi }\end{array}$ & $\begin{array}{l}\text { Evet aldım. Yeterli olduğunu } \\
\text { düşünüyorum. }\end{array}$ \\
\hline Ö2 & 8 & $\mathrm{E}$ & 34 & 4 & Lisans & $\begin{array}{l}\text { Eğitim } \\
\text { Fakültesi }\end{array}$ & $\begin{array}{l}\text { Evet aldım. Ancak yeterli olduğunu } \\
\text { düşünmüyorum. }\end{array}$ \\
\hline Ö3 & 5 & $\mathrm{~K}$ & 26 & 4 & Lisans & $\begin{array}{l}\text { Eğitim } \\
\text { Fakültesi }\end{array}$ & $\begin{array}{l}\text { Özel gereksinimli öğrencilere yönelik } \\
\text { hizmet içi eğitim almadım. }\end{array}$ \\
\hline Ö4 & 16 & $\mathrm{E}$ & 40 & 2 & Lisans & $\begin{array}{l}\text { Eğitim } \\
\text { Fakültesi }\end{array}$ & $\begin{array}{l}\text { Evet aldım. Yeterli olduğunu } \\
\text { düşünüyorum. }\end{array}$ \\
\hline 0̈5 & 9 & $\mathrm{~K}$ & 30 & 3 & Lisans & $\begin{array}{l}\text { Eğitim } \\
\text { Fakültesi }\end{array}$ & Evet aldım. Ama ihtiyacı karşılamadı. \\
\hline Ö6 & 18 & $\mathrm{E}$ & 42 & 4 & Lisans & $\begin{array}{l}\text { Eğitim } \\
\text { Fakültesi }\end{array}$ & Evet aldım. Ama ihtiyacı karşılamadı. \\
\hline Ö7 & 12 & $\mathrm{~K}$ & 34 & 1 & Lisans & $\begin{array}{l}\text { Eğitim } \\
\text { Fakültesi }\end{array}$ & $\begin{array}{l}\text { Rehberlik ve Özel öğrenme güçlüğü } \\
\text { üzerine hizmet içi eğitim aldım. }\end{array}$ \\
\hline Ö8 & 16 & $\mathrm{E}$ & 42 & 1 & Lisans & $\begin{array}{l}\text { Eğitim } \\
\text { Fakültesi }\end{array}$ & $\begin{array}{l}\text { Özel gereksinimli öğrencilere yönelik } \\
\text { hizmet içi eğitim almadım. }\end{array}$ \\
\hline
\end{tabular}




\begin{tabular}{llllllll}
\hline Ö9 & 18 & E & 41 & 1 & Lisans & $\begin{array}{l}\text { Eğitim } \\
\text { Fakültesi }\end{array}$ & $\begin{array}{l}\text { Evet aldım. Özel gereksinimli } \\
\text { oggrencilere yönelik hizmet içi eğitim } \\
\text { aldım. }\end{array}$ \\
\hline Ö10 & 22 & E & 49 & 3 & Lisans & $\begin{array}{l}\text { Eğitim } \\
\text { Fakültesi }\end{array}$ & $\begin{array}{l}\text { Evet aldım. Özel gereksinimli } \\
\text { oggrencilere yönelik hizmet içi eğitim } \\
\text { aldım. }\end{array}$ \\
\hline
\end{tabular}

Araştırmada görüşleri alınan sınıf öğretmenleriyle ilgili ön bilgiler çeşitli değişkenler açısından yukarıda sunulmuştur. Tablo 1 incelendiğinde, sınıf öğretmenlerinin hizmet yılları en az 6 (Ö1), en fazla ise 22 (Ö10) olduğu görülmektedir. Öğretmenlerin hizmet yılları ortalaması 13 olarak hesaplanmıştır. Görüşleri alınan tüm sınıf öğretmenleri Eğitim Fakültesinden mezun olmakla birlikte tamamı lisans mezunudur. Araştırmada görüşleri alınan sınıf öğretmenlerinin özel gereksinimli öğrencilere yönelik hizmet içi eğitim alma durumları, özel gereksinimli öğrencilerle ilgili yapacağı uygulamalar açısından önemlidir. Hizmet içi eğitimle ilgili görüşleri alınan sınıf öğretmenlerinin çoğunluğu $(\mathrm{f}=8)$, özel gereksinimli öğrencilere yönelik eğitim aldığını ifade etmektedirler. Hizmet içi eğitim aldıklarını belirten öğretmenler de eğitimlerin kendileri için yetersiz olduğunu ifade etmişlerdir. Bununla birlikte öğretmenlerden ikisi (Ö3 ve Ö8) özel gereksinimli öğrencilere yönelik herhangi bir hizmet içi eğitim almadıklarını ifade etmişlerdir.

\subsection{Veri Toplama Araçları}

$\mathrm{Bu}$ araştırmada veriler hazırlanan yarı yapılandırılmış görüşme tekniğiyle elde edilmiştir. Yarı yapılandırılmış görüşme tekniğinin araştırmayı yapan kişiye sağladığı en önemli kolaylık görüşmenin önceden hazırlanmış verilere bağlı olarak sürdürülebilmesi nedeniyle sistematik ve karşılaştırılabilir bilgi sunmasıdır (Yıldırım \& Şimşek, 2016). Hazırlanan yarı yapılandırılmış görüşme formu pilot uygulama amacıyla bir öğretmene uygulanmıştır. Yapılan uygulamadan sonra uzman incelemesinden de yararlanarak görüşme sorularına son şekli verilmiştir. Görüşme formu, ilk bölümde öğretmen bilgileri; ikinci bölümde ise öğretmenlerin özel gereksinimli öğrencilere yönelik eğitim alıp almadığ bu öğrencilerin hangi alanlarda eksiklik yaşadığı ve bu durumun velilere bildirilip bildirilmediği, öğretmenlerin özel gereksinimli öğrencilerin yetersizlik yaşadığı alanlarda kendilerini yeterli görüp görmediği, bu öğrencilerin akademik özelliklerinin neler olduğu, bu öğrencilerin sosyal ortamlara desteklenmesi ve okulda akran kabulü için ne tür uygulamalar yaptığı, öğretmenlerin öğrenme-öğretme sürecinde bu öğrencilere yönelik ne tür uygulamalar gerçekleştirdiği, hangi zorluklarla karşılaştı̆̆ 1 ve kimlerden destek aldığı şeklinde sorulardan oluşmaktadır. Yarı yapılandırılmış görüşme formunda hazırlanan sorular hazırlandığ 1 şekliyle sorulur ve katılımcılara cevaplamaları konusunda belli bir dereceye kadar aktiflik ve serbestlik tanınır (Ekiz, 2013).

Sınıfinda özel gereksinimli öğrenci bulunan sınıf öğretmenlerinin öğrenme-öğretme sürecinde yaptıkları uygulamalar ve karşılaştıkları güçlükler hakkındaki görüşlerini belirlemek amacıyla yapılan araştırmada tamamen gönüllülük esasına dayalı olarak Bayburt il merkezinde farklı okullarda çalışmakta olan 10 sınıf öğretmeni seçilmiştir. Görüşmelerden önce görüşme onay formu katılımcılara okutularak imzaları alınmıştır. Derslerin aksatılmaması adına öğretmenlerin uygun olduğu zamanlarda (okul çıkışı, teneffüs araları) görüşmeler yapılmıştır. Bu görüşmeler öğretmenlerin de kabulü ile ses kayıt cihazı ile kayıt altına alınmıştır. Ayrıca katılımcıların kendilerini rahat hissedebilmeleri ve görüşlerini açı bir şekilde ifade edebilmeleri amacıyla samimi bir iletişim tarzı tercih edilmiştir. Görüşmelerin uzunluğu 10 ile 15 dakika arasında değişmiş olup, tüm görüşmeler toplam 120 dakika sürmüştür. Ses kayıt cihazı ile kaydedilen görüşmeler bilgisayar ortamında yazıya aktarılmış, aktarılan görüşmelerin çıktısı alındıktan sonra öğretmenlerin ekleme ve çıkarma yapmaları için geri dağıtılmıştır. Öğretmenler tarafından yapılan ekleme ve çıkarma işlemlerinden sonra veriler son şeklini almıştır.

\subsection{Verilerin Analizi}

Araştırmada, toplanan verilerin analizi için temel düzey analiz bağlamında betimsel analiz ve üst düzey analiz bağlamında içerik analizi (Ekiz, 2013) kullanılmıştır. Betimsel analizde özetlenen ve yorumlanan veriler, içerik analizinde daha derin bir işleme tabi tutulur ve betimsel bir yaklaşımla fark edilemeyen kavram ve temalar bu analiz sonucu ortaya çıkarılabilir (Yıldırım \& Şimşek, 2016; Ekiz, 2013). İçerik analizi, toplanan verilerin derinlemesine analiz edilmesini gerektirir ve önceden belirgin 
olamayan temaların ve boyutların ortaya çıkarılmasına olanak tanır (Yıldırım \& Şimşek, 2016). Burada yapacağımız işlem, birbirine benzeyen verileri belirli kodlar ve temalar çerçevesinde bir araya getirmek ve bunları okuyucunun anlayacağı şekilde düzenlemek olacaktır. Bu çerçevede araştırma sorularından yararlanarak, araştırmanın kavramsal çerçevesi belirlenmiş, elde edilen verilen bu çerçevede düzenlenmiş, araştırmada incelediğimiz konuyu içeren veriler seçilmiş, gerekli görülen yerlerde araştırmacı görüşlerine başvurulmuş ve gerekli yorumlamalar yapılmıştır (Çepni, 2012).

\subsection{Geçerlik ve Güvenirlik}

Araştırmanın bilimsel bir nitelik kazanabilmesi açısından araştırmada geçerlik ve güvenirlik çalışmaları önemli iki kavramdır (Yıldırım \& Şimşek, 2016). Sınıfında özel gereksinimli öğrenci bulunan sınıf öğretmenlerinin yapmış oldukları uygulamalar ve karşılaştıkları güçlüklerin belirlenmesi amacıyla uzman görüşüne de başvurularak hazırlanan yarı yapılandırılmış görüşme formu kullanılmıştır. Uzman görüşünden yararlanmak araştırmanın kapsam geçerliliğini artırmaya yönelik bir uygulamadır (Çepni, 2012). Yapılan görüşmeler esnasında ses kayıt cihazı ile kayıt altına alınmakla beraber not da tutulmuştur. Ardından bu kayıtlar ve notlardan yararlanılarak veriler düz yazıya çevrilmiştir. Veri analizi neticesinde elde edilen bulgular tablolar halinde sunulmuştur. Aynı zamanda yüz yüze görüşmeler yoluyla ayrıntılı ve derinlemesine bilgi toplama nitel araştırmada geçerliliği sağlamaya yarayan önemli bir özelliktir (Yıldırım \& Şimşek, 2016). Yapılan görüşmelerden sonra veriler katılımcıya özetlenmiş ve katılımcıdan bunların doğruluğuna ilişkin düşüncelerini belirtmesi istenerek katılımcı teyidi gerçekleştirilmiştir. Araştırmada verilerin analiz edilmesi ve yorumlanması konusunda başka bir araştırmacının görüşlerinden yararlanılması, verilerin amaca uygun bir şekilde toplanması için gerekli sürenin kullanılması yapılan araştırmanın güvenilir olduğunu göstermektedir (Alderman et al., 1984; Akt.:Ekiz, 2013). Bu araştırmada söz konusu metotlar kullanılarak güvenilirlik artırılmaya çalışılmıştır. Araştırma makalelerinde, buraya yöntem kısmı eklenilmeli ve yukarıdaki önerilere dikkat edilmelidir.

\section{BULGULAR}

Bu bölümde, araştırma soruları çerçevesinde, sınıfında özel gereksinimli öğrenci bulunan sınıf öğretmenlerinin öğrenme-öğretme sürecinde yaptıkları uygulamalar ve karşılaştıkları güçlüklere ilişkin görüşleri sunulmakta ve yorumlanmaktadır. Bu doğrultuda, sınıf öğretmenlerinin özel gereksinimli öğrencilere yönelik eğitim durumları ve yeterlilikleri, özel gereksinimli öğrencilerin özellikleri, belirlenmesi ve yapılan faaliyetler, sınıf öğretmenlerinin öğrenme öğretme sürecinde yapmış oldukları uygulamalar, karşılaştıkları sorunlar ve aldıkları destekler hakkında bilgilere yer verilmiş ve yorumlanmıştır. Ayrıca her bir araştırma sorusuna ilişkin kod ve kategorilerin yer aldığı şekiller sunulmuştur.

\subsection{Sınıf Öğretmenlerinin Özel Gereksinimli Öğrencilere Yönelik Eğitim Durumları Ve Yeterlilikleri}

Sınıf öğretmenlerinin özel gereksinimli öğrencilere yönelik eğitim durumları ve yeterliliklerine ilişkin görüşleri Şekil 1'de sunulmuştur.

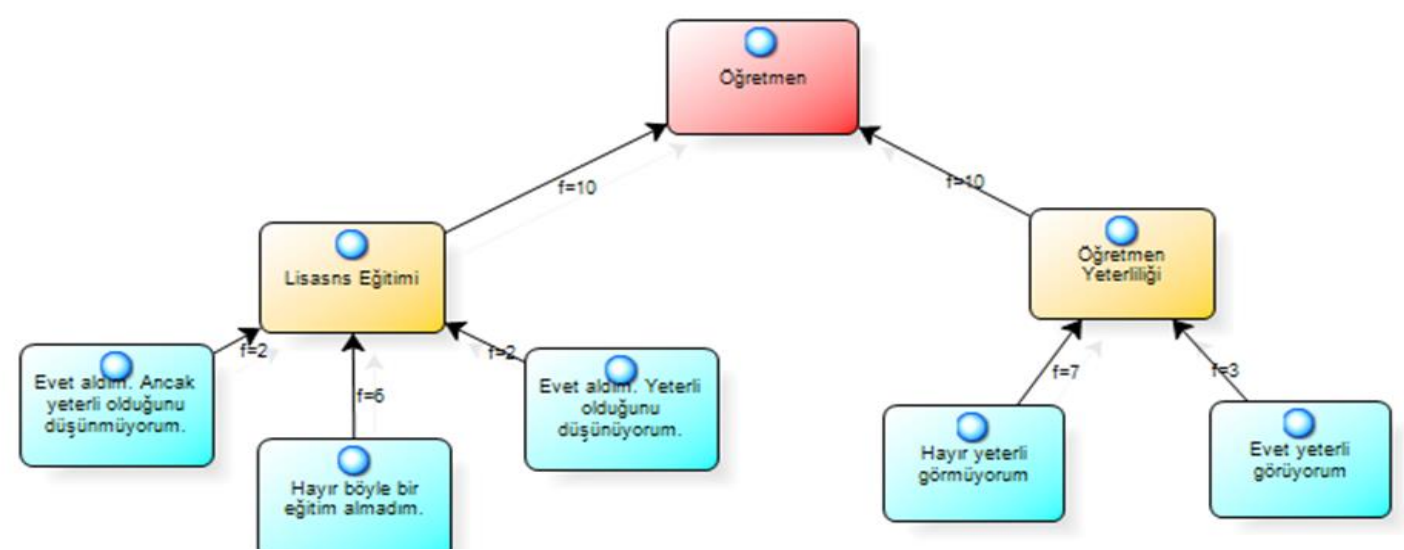

Şekil 1: Sinıf ögretmenlerinin özel gereksinimli öğrencilere yönelik eğitim durumları ve yeterlilikleri 
Hazırlanan yarı yapılandırılmış görüşme formunda, öğretmenlerin eğitim durumlarını ve yeterliliklerini belirlemeye yönelik sorulara yer verilmiştir. Öğretmenlere üniversitede özel gereksinimli öğrencilere yönelik herhangi bir eğitim alıp almadıkları ve eğer aldılarsa kendilerini yeterli görüp görmedikleri sorulmuştur. Ayrıca öğretmenlere özel gereksinimli öğrencilerinin yetersizliğiyle baş etmede kendilerini yeterli görüp görmedikleri de sorulmuştur. Bu sorularla öğretmenlere özel gereksinimli öğrenciler için üniversitede verilen eğitimin ve öğretmenlerin konuyla baş etme becerilerinin belirlenmesi amaçlanmıştır. Araştırmaya katılan sınıf öğretmenlerinin özel gereksinimli öğrencilere yönelik eğitim durumları ve yeterliliklerinin belirlenmesi amacıyla elde edilen bulgular Tablo 2' de verilmiştir.

Tablo 2. Sınıf öğretmenlerinin özel gereksinimli öğrencilere yönelik eğitim durumları

\begin{tabular}{|c|c|c|c|}
\hline \multirow{2}{*}{ Kod } & \multicolumn{3}{|c|}{$\begin{array}{l}\text { Özel gereksinimli öğrencilere yönelik üniversitede bir eğitim aldınız mı? Bu eğitimin yeterli } \\
\text { olduğunu düşünüyor musunuz? }\end{array}$} \\
\hline & $\begin{array}{l}\text { Evet aldım. Yeterli olduğunu } \\
\text { düşünüyorum. }\end{array}$ & $\begin{array}{l}\text { Evet aldım. Ancak yeterli } \\
\text { olduğunu düşünmüyorum. }\end{array}$ & Hayır, böyle bir eğitim almadım. \\
\hline Ö1 & & $\checkmark$ & \\
\hline Ö2 & & & $\checkmark$ \\
\hline Ö3 & $\checkmark$ & & \\
\hline Ö4 & $\checkmark$ & & \\
\hline 0̈5 & & & $\checkmark$ \\
\hline Ö6 & & & $\checkmark$ \\
\hline Ö7 & & & $\checkmark$ \\
\hline Ö8 & & & $\checkmark$ \\
\hline Ö9 & & & $\checkmark$ \\
\hline Ö10 & & $\checkmark$ & \\
\hline Toplam & 2 & 2 & 6 \\
\hline
\end{tabular}

Tablo 2 incelendiğinde, öğretmenlerin çoğunluğu üniversitede özel gereksinimli öğrencilere yönelik herhangi bir eğitim almadıklarını ifade etmektedirler. Üniversitede böyle bir eğitim alan öğretmenlerin ise bir kısmı bu eğitimin yetersiz olduğunu ve ihtiyacı karşılamaktan uzak olduğunu belirtmişlerdir. Bu eğitimlerin yetersiz olmasının sebebi olarak da yüzeysel ve kısa süreli olması gösterilmiştir. Çok az bir kısmı özel gereksinimli öğrencilere yönelik eğitim aldığını ve bu eğitimin ihtiyaçlarını karşıladığını ifade etmiştir. Üniversitede özel gereksinimli öğrencilere yönelik eğitim alan bir öğretmen bunu şu şekilde ifade etmektedir: “...almışıtı. Sürekli hocamız bize BEP diye tutturuyordu. Ama şimdi işimize çok yarıyor". Özel gereksinimli öğrencilere yönelik herhangi bir eğitim almayan öğretmenler bu eksikliklerini meslekte öğrenerek gidermeye çalışmaktadırlar. Bu konuyu bir öğretmen: "Üniversitede özel gereksinimli ögrencilerle ilgili bir eğitim almadim. BEP nasll hazırlanır, kaynaştırma nedir hiç ögretmediler. Daha çok meslekte ögreniyoruz" şeklinde ifade etmektedir.

Ayrıca sınıf öğretmenlerinin özel gereksinimli öğrenciler konusunda kendilerini yeterli görüp görmediği ile ilgili veriler toplanmıştır. Bunun için öğretmenlere özel gereksinimli öğrencinin yetersizliğiyle başa çıkmada kendilerini yeterli görüp görmedikleri sorusu yöneltilmiştir. Toplanan veriler Tablo 3'te sunulmuştur. 
Tablo 3. Sınıf öğretmenlerinin özel gereksinimli öğrencilere yönelik yeterlilikleri

\begin{tabular}{|c|c|c|c|}
\hline \multirow{2}{*}{ Kod } & \multicolumn{3}{|c|}{ Özel gereksinimli öğrencinizin yetersizliğiyle başa çıkmada kendinizi yeterli görüyor musunuz? } \\
\hline & $\begin{array}{l}\text { Evet, yeterli } \\
\text { görüyorum }\end{array}$ & Açıklama & $\begin{array}{l}\text { Hayır, yeterli } \\
\text { görmüyorum }\end{array}$ \\
\hline Ö1 & & Özel zaman ve ilgi gerektiren bir süreç. Yavaş ilerliyor. & $\checkmark$ \\
\hline Ö2 & $\checkmark$ & Meslekte aldığım hizmet içi eğitim ve deneyim. & \\
\hline$\ddot{03}$ & & $\begin{array}{l}\text { Herhangi bir ders ve hizmet içi eğitim almadığım için ne yapacağımı } \\
\text { bilmiyorum. }\end{array}$ & $\checkmark$ \\
\hline Ö4 & $\checkmark$ & $\begin{array}{l}\text { Genel itibariyle yeterli görüyorum. Bazen yetmediğimiz durumlar } \\
\text { olabiliyor. }\end{array}$ & \\
\hline Ö5 & $\checkmark$ & $\begin{array}{l}\text { İlk kez böyle bir öğrencim olduğunda ne yapacağımı bilemedim. Destek } \\
\text { eğitim ve BEP'le birlikte sürecin üstesinden gelebildim. }\end{array}$ & \\
\hline Ö6 & & $\begin{array}{l}\text { Herhangi bir ders ve hizmet içi eğitim almadığım için ne yapacağımı } \\
\text { bilmiyorum. }\end{array}$ & $\checkmark$ \\
\hline Ö7 & & $\begin{array}{l}\text { Herhangi bir eğitim almadım. Verilen seminerler de zorunlu tutulduğu için } \\
\text { göstermelik oldu. }\end{array}$ & $\checkmark$ \\
\hline Ö8 & & Tek başıma yeterli değilim gerekli işbirlikleri yapılırsa yeterli olabilirim. & $\checkmark$ \\
\hline Ö9 & & Duruma ayak uyduramıyorum. & $\checkmark$ \\
\hline Ö10 & & Tek başıma yeterli değilim gerekli işbirlikleri yapılırsa yeterli olabilirim. & $\checkmark$ \\
\hline Toplam & 3 & & 7 \\
\hline
\end{tabular}

Yukarıdaki bulgular incelendiğinde, görüşlerinden yararlandığımız sınıf öğretmenlerinin çoğunluğu ( $\mathrm{f}=7$ ) özel gereksinimli öğrencilerin yetersizliğiyle başa çıkmada kendilerini yetersiz görmektedirler. Sınıf öğretmenlerinin, özel gereksinimli öğrencilere yönelik kendilerini yetersiz görmelerinin sebepleri arasında, herhangi bir ders ve hizmet içi eğitim almamış olmaları, yapılan hizmet içi eğitim seminerlerinin göstermelik yapıldığı, gerekli desteklerin gösterilmediği ve işbirliği noktasında sıkıntılar yaşanması gibi durumlar sayılabilir. Kendilerini yeterli gören öğretmenler ise sürecin başında kendilerini yetersiz gördükleri ancak verilen destek ve hizmet içi eğitimlerle bu durumun üstesinden geldiklerini ifade etmektedirler. 


\section{2. Özel Gereksinimli Öğrencilerin Özellikleri, Belirlenmesi ve Yapılan Faaliyetler}

Özel gereksinimli öğrencilerin özellikleri, belirlenmesi ve yapılan faaliyetler temasına ilişkin kategori ve alt kategoriler Şekil 2'de gösterilmiştir.

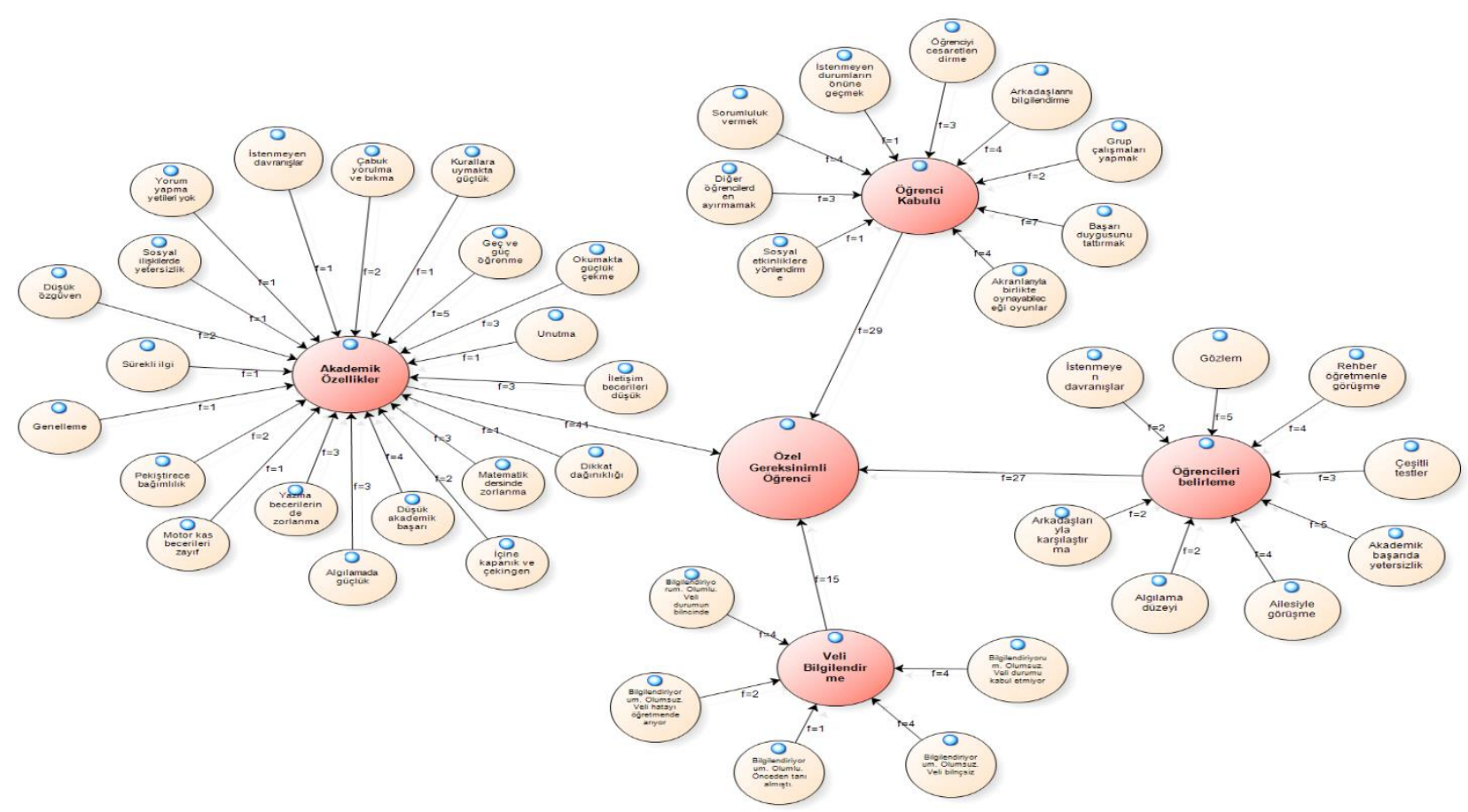

Şekil 2: Özel gereksinimli öğrencilerin özellikleri, belirlenmesi ve yapılan faaliyetler

Özel gereksinimli öğrencilerin belirlenmesi bu öğrencilerin özelliklerinin bilinmesiyle sağlanabilir. Sınıf öğretmenleri özel gereksinimli öğrencilerin özelliklerinin yetersizlik türlerine göre değiştiğini belirtmektedirler. Bunun doğrultusunda öğretmenlere özel gereksinimli öğrencilerin hangi özelliklere sahip olduğu sorulmuştur. Buna yönelik elde edilen bulgular Tablo 4'te sunulmuştur.

Tablo 4. Sınıf öğretmeni gözüyle özel gereksinimli öğrencilerin özellikleri

\begin{tabular}{lll}
\hline \multicolumn{1}{c}{$\begin{array}{c}\text { Özel Gereksinimli Öğrencilerin Belirgin } \\
\text { Özellikleri }\end{array}$} & \multicolumn{1}{c}{ Öğretmenler } & Frekans (f) \\
\hline Geç ve güç öğreniyorlar & Ö3, Ö5, Ö6, Ö7, Ö9, & 5 \\
\hline Akademik başarıları akranlarına göre düşük & Ö2, Ö4, Ö8, Ö10 & 4 \\
\hline Okumakta güçlük çekerler & Ö1, Ö4, Ö5 & 3 \\
\hline Yazma becerilerinde zorlanma & Ö1, Ö4, Ö5, & 3 \\
\hline Matematik dersinde zorlanma & Ö1, Ö4, Ö5 & 3 \\
\hline Algılamada güçlük yaşıorlar & Ö1, Ö2, Ö9, & 3 \\
\hline Iletişim becerileri çok düşük & Ö3, Ö5, Ö7, & 3 \\
\hline Pekiştirece çok ihtiyaç duyuyorlar & Ö3, Ö9, & 2 \\
\hline İçine kapanık ve çekingen öğrencilerdir & Ö5, Ö8, & 2 \\
\hline Düşük özgüvene sahiptirler & Ö6, Ö8, & 2 \\
\hline Çabuk yorulma ve bıkma & Ö9, Ö10 & 2 \\
\hline Öğrendiklerini çabuk unutuyorlar & Ö2, & 1 \\
\hline İstenmeyen davranışlar sergiliyorlar & Ö1, & 1 \\
\hline
\end{tabular}




\begin{tabular}{lll}
\hline Dikkatleri çok dağınık & Ö3, & 1 \\
\hline Motor kas becerilerinde sıkıntı yaşıyorlar & Ö3, & 1 \\
\hline Yorum yapma yetileri yoktur & Ö4, & 1 \\
\hline $\begin{array}{l}\text { Genelleme sıkıntıları vardır. Öğrendiklerini } \\
\text { uygulamada güçlük çekerler. }\end{array}$ & Ö7, & 1 \\
\hline Sosyal ilişkilerde yetersizlik & Ö7, & 1 \\
\hline Kurallara uymakta güçlük yaşıyorlar & Ö9, & 1 \\
\hline Sürekli ilgi bekliyorlar & Ö9, & 1 \\
\hline
\end{tabular}

Sınıf öğretmenleri, özel gereksinimli öğrencilerin özellikleriyle ilgili farklı özellikler belirtmektedirler. Sınıflarında bulunan özel gereksinimli öğrencilerin birbirlerinden farklı yetersizliklere sahip olması bu farklılığı ortaya çıkarmaktadır. Benzer özellikleri ifade eden öğretmenler de mevcuttur. Sınıf öğretmenlerinin üzerinde en fazla durduğu özellikler, özel gereksinimli öğrencilerin akranlarına göre geç öğrenmeleri ve öğrenirken zorlanmalarının yanında akademik başarılarda da akranlarına göre geride kalmaktadırlar. Ayrıca sınıf öğretmenleri özel gereksinimli öğrencilerin, okuma, yazma, matematik dersinde zorlanma, algılamada güçlük yaşama ve iletişim becerilerinde düşüklük gibi özelliklere sahip olduklarını belirtmektedirler. Özel gereksinimli öğrencilerin düşük özgüvene sahip olduğu, dolayısıyla içine kapanık ve çekingen oldukları, ayrıca pekiştirece çok ihtiyaç duydukları ve çabuk yorulup, bıktıkları da öğretmenler tarafından ifade edilmiştir. Öğrendiklerini çabuk unutma ve yeni durumlara genellemede sıkıntı yaşama, kurallara uymakta güçlük çekme ve istenmeyen davranışlar sergileme, motor kas becerilerinde sıkıntı yaşama, sosyal ilişkilerde yetersizlik ve sürekli ilgi beklemeleri bu öğrencilerin diğer özellikleri olarak sayılabilir.

Sınıf öğretmenlerinin sınıfında bulunan özel gereksinimli öğrencileri belirleyebilmesi öğrencinin gelişimi, öğretimin bireyselleştirilmesi ve öğrencinin kabulü açısından önemlidir. Öğretmenler öğrenme-öğretme sürecinin farklı aşamalarında özel gereksinimli öğrenciler için yerinde ve doğru kararlar verebilmek için bu öğrencilerin belirlenmesine ihtiyaç duyarlar. Araştırmada sınıf öğretmenlerinin özel gereksinimli öğrencileri tanılama noktasında sıkıntı yaşamadığı tespit edilmiştir. $\mathrm{Bu}$ doğrultuda sınıf öğretmenlerine özel gereksinimli öğrencileri tespit etmek için hangi yolları kullandığ 1 sorulmuş ve bulgular Tablo 5 'te sunulmuştur.

Tablo 5. Sınıf öğretmenlerinin özel gereksinimli öğrencileri belirlemek için kullandığı yöntemler

Özel gereksinimli öğrencilerinizi belirlemek için ne tür çalş̧malar yapıyorsunuz?

\begin{tabular}{|c|c|c|c|c|c|c|c|c|}
\hline Kod & $\begin{array}{l}\text { Ailesiyle } \\
\text { görüşme }\end{array}$ & $\begin{array}{c}\text { Akademik } \\
\text { başarıda } \\
\text { yetersizlik }\end{array}$ & $\begin{array}{l}\text { Algılama } \\
\text { düzeyi }\end{array}$ & $\begin{array}{l}\text { Arkadaşlarıyla } \\
\text { karşılaştırma }\end{array}$ & $\begin{array}{l}\text { Çeşitli } \\
\text { testler }\end{array}$ & Gözlem & $\begin{array}{l}\text { İstenmeyen } \\
\text { davranışlar }\end{array}$ & $\begin{array}{c}\text { Rehber } \\
\text { öğretmenle } \\
\text { görüşme }\end{array}$ \\
\hline Ö1 & & & $\checkmark$ & & $\checkmark$ & $\checkmark$ & & \\
\hline Ö2 & & $\checkmark$ & & & & & & \\
\hline Ö3 & $\checkmark$ & & & $\checkmark$ & & $\checkmark$ & $\checkmark$ & $\checkmark$ \\
\hline Ö4 & & & & & $\checkmark$ & & & $\checkmark$ \\
\hline Ö5 & & $\checkmark$ & & $\checkmark$ & & & $\checkmark$ & \\
\hline Ö6 & & & & & & $\checkmark$ & & $\checkmark$ \\
\hline Ö7 & $\checkmark$ & & & & & $\checkmark$ & & \\
\hline Ö8 & $\checkmark$ & $\checkmark$ & & & & & & \\
\hline Ö9 & & $\checkmark$ & $\checkmark$ & & & & & \\
\hline Ö10 & $\checkmark$ & $\checkmark$ & & & $\checkmark$ & $\checkmark$ & & $\checkmark$ \\
\hline
\end{tabular}




\begin{tabular}{lllllllll} 
Top & 4 & 5 & 2 & 2 & 3 & 5 & 2 & 4 \\
\hline
\end{tabular}

Bulgular incelendiğinde sınıf öğretmenlerinin sınıfında bulunan özel gereksinimli öğrencileri belirleme noktasında sıkıntı yaşamadıkları görülmektedir. Sadece bir öğretmen (Ö6) bu konuda kendini yetersiz görmektedir. Ö6 bu durumu: "Belirtiler hususunda bizim çok da bilgimiz yok ve böyle ögrencilerin farkına varamıyoruz" şeklinde ifade etmektedir. Özel gereksinimli öğrencilerin belirlenmesi noktasında Ö5: "Akademik başarı olarak arkadaşlarından geride kalıyor, farklı davranışlar sergiliyor, çekingen ve içe kapanık oluyorlar, sosyal ilişkilerde zayıflık gibi etmenler şüphelenmemize neden oluyor" ş̧eklinde görüş bildirmiştir. Bu konuda bir diğer öğretmen ise: "Öğrenciyi sinıf içinde ve dışında gözlemliyorum, ailesiyle görüşüyorum ve testler uyguluyorum" şeklinde görüş bildirmiştir. Sınıf öğretmenleri özel gereksinimli öğrencileri belirlerken, "akademik başarıda yetersizlik" ve "gözlem" çalışmaları gerçekleştirmektedir. Daha sonra ailesiyle görüşme, rehber öğretmenle görüşme ve çeşitler testler uygulayarak özel gereksinimli öğrencileri belirlemektedirler. Son olarak, sinıf öğretmenlerinin özel gereksinimli öğrencileri belirlerken kullandığı faktörler öğretmenden öğretmene ve yetersizliğin türüne göre değişiklik göstermektedir.

Özel gereksinimli öğrencilerin sosyal ortamlarda desteklenmesi ve akranları tarafindan kabul edilmesi, bu öğrencilerin genel eğitim sınıflarında akranlarıyla birlikte eğitilmelerine firsat vermektedir. Özel gereksinimli öğrencilerin toplumsal ve sosyal kabulünün yanında akranları tarafından da kabul edilmesi öğrenme-öğretme sürecinde bu öğrencilerin başarılı bir şekilde kaynaştırılması için önemlidir. Bu konuda sınıf öğretmenleri hem sınıf içinde hem de dışında bu öğrencilerin kabulü için çalışmalar yapmaktadırlar. Görüşme yaptığımız sınıf öğretmenlerinin bu konuda nasıl uygulamalar yaptıklarıyla ilgili bulgular Tablo 6'da sunulmuştur.

Tablo 6. Özel gereksinimli öğrencilerin sosyal ortamlarda desteklenmesi ve akran kabulü için yapılan çalışmalar

\begin{tabular}{lll}
\hline $\begin{array}{l}\text { Özel Gereksinimli Öğrencilerin Desteklenmesi ve } \\
\text { Kabulü İçin Yapılan Çalışmalar }\end{array}$ & Öğretmenler & Frekans (f) \\
\hline $\begin{array}{l}\text { Yapabildikleri üzerine odaklanarak başarı duygusunu } \\
\text { tattırmak }\end{array}$ & Ö1, Ö4, Ö5, Ö6, Ö8, Ö9, Ö10 & 7 \\
\hline Yapabileceği sorumluluklar vermek & Ö6, Ö7, Ö9, Ö10 & 4 \\
\hline Akranlarına, öğrencinin durumunu anlatma & Ö1, Ö2, Ö3, Ö9 & 4 \\
\hline Akranlarıyla birlikte oynayabileceği oyunlar & Ö1, Ö3, Ö8, Ö10 & 4 \\
\hline $\begin{array}{l}\text { Öğrenciyi cesaretlendirmek } \\
\text { Diğer öğrencilerden ayırmamak }\end{array}$ & Ö1, Ö2, Ö7 & 3 \\
\hline Grup çalışmalar1 yapmak & Ö2, Ö4, Ö9 & 3 \\
\hline $\begin{array}{l}\text { Dalga geçme, alay etme vb. istenmeyen durumların önüne } \\
\text { geçme }\end{array}$ & Ö7, Ö8 & 2 \\
\hline \begin{tabular}{l} 
Okul diş1 sosyal etkinliklere yönlendirmek \\
\hline
\end{tabular}
\end{tabular}

Görüşlerine başvurulan sınıf öğretmenlerinin özel gereksinimli öğrencilerin sosyal ortamlarda desteklenmesi ve akranları tarafından kabul edilmesi için yaptığı çalışmalar arasında en fazla görüş bildirdikleri çalışmanın, yapabildikleri üzerine odaklanarak başarı duygusunu tattırmak olduğu görülmektedir. Bu çalışmayı sırasıyla, yapabileceği sorumluluklar vermek, akranlarına öğrencinin durumunu anlatmak, akranlarıyla birlikte oynayabileceği oyunlar, öğrenciyi cesaretlendirmek, diğer öğrencilerden ayırmamak ve grup çalışmaları yapmak takip etmektedir. Özel gereksinimli öğrencileri sosyal etkinliklere yönlendirmek ve dalga geçme alay etme vb. istenmeyen durumların önüne geçme çalışmaları ise bu konuda öğretmenlerin en az yararlandıkları çalışmalar olarak belirtilmektedir. Özel gereksinimli öğrencilerin kabulü özgüvenleri açısından önem ifade etmektedir. Bu konuda Ö6: "Öğrencilerin özgüvenlerinin artırılması için çaba sarf edilmesi gerekir. Bu öğrencilerin başarı 
duygularını artırmak için öğrencinin yapabildikleri üzerinden sorumluluk verilmesi gerekir. Ben zaten yapamıyorum deyip bırakılmamall. Ayrıca bu tür öğrenciler okul dışında sosyal faaliyetlere (yüzme, spor, enstrüman çalma vs.) yönlendirilebilir. Bu ögrenciler her ne kadar yetersiz olsalar da bazı alanlarda çok iyiler. Bu alanların değerlendirilmesi gerekir" şeklinde düşüncelerini belirtmiştir.

Anne babalar, çocukların eğitimlerinde sınıf öğretmenlerine çocukları hakkında bilgi veren, çocukların okulda öğrendiklerini ev ortamına ve diğer sosyal ortamlara aktarmalarında çocuklara yardımcı olan ve öğretmene öğrenciyle ilgili her türlü konuda destek vermektedirler.

$\mathrm{Bu}$ nedenle sınıf öğretmenleri hazırlayacakları programlarda anne babaları dikkate alacaklardır. Hatta anne baba görüşleri öğrenme-öğretme sürecine yön verecektir. Dolayısıyla öğretmen veli iletişimi önem kazanmaktadır. Bu konuda görüşme yaptığımız sınıf öğretmenlerine özel gereksinimli öğrencilerin durumlarını velileriyle paylaşıp paylaşmadıklarını, eğer paylaşıyorlarsa velilerden nasıl tepkiler aldıklarını ve tepkilerinin nedenlerini sorduk. Sınıf öğretmenlerinden aldığımız cevaplar Tablo 7'de sunulmuştur.

Tablo 7. Sınıf öğretmenlerinin özel gereksinimli öğrencilerin velileriyle iletişimi

\begin{tabular}{|c|c|c|c|c|c|}
\hline \multirow[b]{2}{*}{ Kod } & \multicolumn{5}{|c|}{$\begin{array}{l}\text { Özel gereksinimli öğrencilerinizin velilerini bilgilendiriyor musunuz? Velilerin duruma tepkileri } \\
\text { olumlu mu olumsuz mu? Neden? }\end{array}$} \\
\hline & $\begin{array}{l}\text { Bilgilendiriyorum. } \\
\text { Olumlu: Önceden } \\
\text { tanı almıştı. }\end{array}$ & $\begin{array}{l}\text { Bilgilendiriyorum. } \\
\text { Olumlu: Veli } \\
\text { durumun bilincinde }\end{array}$ & $\begin{array}{c}\text { Bilgilendiriyorum. } \\
\text { Olumsuz: Veli } \\
\text { bilinçsiz }\end{array}$ & $\begin{array}{c}\text { Bilgilendiriyorum } \\
\text {. Olumsuz: Veli } \\
\text { durumu kabul } \\
\text { etmiyor }\end{array}$ & $\begin{array}{c}\text { Bilgilendiriyorum } \\
\text {. Olumsuz: Veli } \\
\text { hatayı } \\
\text { ögretmende } \\
\text { arıyor }\end{array}$ \\
\hline Ö1 & & & $\checkmark$ & $\checkmark$ & \\
\hline Ö2 & & $\checkmark$ & & & \\
\hline Ö3 & & & & & $\checkmark$ \\
\hline Ö4 & & $\checkmark$ & & & \\
\hline Ö5 & & & $\checkmark$ & $\checkmark$ & $\checkmark$ \\
\hline Ö6 & & $\checkmark$ & & & \\
\hline Ö7 & & & $\checkmark$ & $\checkmark$ & \\
\hline Ö8 & & $\checkmark$ & & & \\
\hline Ö9 & $\checkmark$ & & & & \\
\hline Ö10 & & & $\checkmark$ & $\checkmark$ & \\
\hline Toplam & 1 & 4 & 4 & 4 & 2 \\
\hline
\end{tabular}

Sınıf öğretmenlerinin özel gereksinimli öğrencilerin velileriyle iletişimine ait bulgulardan hareketle öğretmenlerin özel gereksinimli öğrencinin durumunu velilere bildirdikleri görülmektedir. Bütün öğretmenler velileri durumdan haberdar etmiştir. Öğretmenlerin bir kısmı velilerin durumu anlayışla karşıladığını belirtmekle birlikte devamında velilerin durumun bilincinde olduğunu ( $\mathrm{f}=4)$ ve öğrencinin önceden tanı aldığını ifade etmiştir. Olumsuz görüş bildiren öğretmenler ise bunun nedeni olarak, velilerin bilinçsiz olması, velinin çeşitli sebeplerden dolayı (çocuğunun etiketlenmesi, toplumda dışlanması vs.) durumu kabul etmemesi ve velilerin sorunu öğretmende araması gibi durumları göstermişlerdir. Bu konuda öğretmenlerin ifadeleri şu şekildedir: “...velileri bilgilendiriyorum. Veliler duruma tepkili kabul etmiyorlar. Çocuklarına bir şeyler eksik gözüyle bakmak istemiyorlar” Ö1.

“...velileri bilgilendiriyorum. Veli bu durumu olumsuz karşıladı. Veliyle yaklaşık 1,5 yıl kavga ettik. Veli durumdan beni sorumlu tutuyordu ve çocuğumla ilgilenmiyorsun gibi tepkilerde bulunuyordu. Illetişimimi artırdı̆̆ımda kadın kabullendi ancak 1,5 yll beni suçladılar" (Ö5). “...bilgilendiriyoruz elbette. Velilerin tepkileri olumlu da olabiliyor olumsuz da. Sinıf ögretmeninin yaklaşımı ev ögrencinin hakkında detaylı açıklamaları bu durumu olumluya çevirebiliyor" (Ö4). Öğretmenlerin ifadeleri, öğretmenin veliyle iletişiminin ne kadar önemli olduğunu göstermektedir. 


\subsection{Sınıf Öğretmenlerinin Öğrenme Öğretme Sürecinde Yapmış Oldukları Uygulamalar, Karşılaştıkları Sorunlar ve Aldıkları Destekler}

Bu temaya ilişkin kategori ve alt kategoriler Şekil 3’te sunulmuştur.

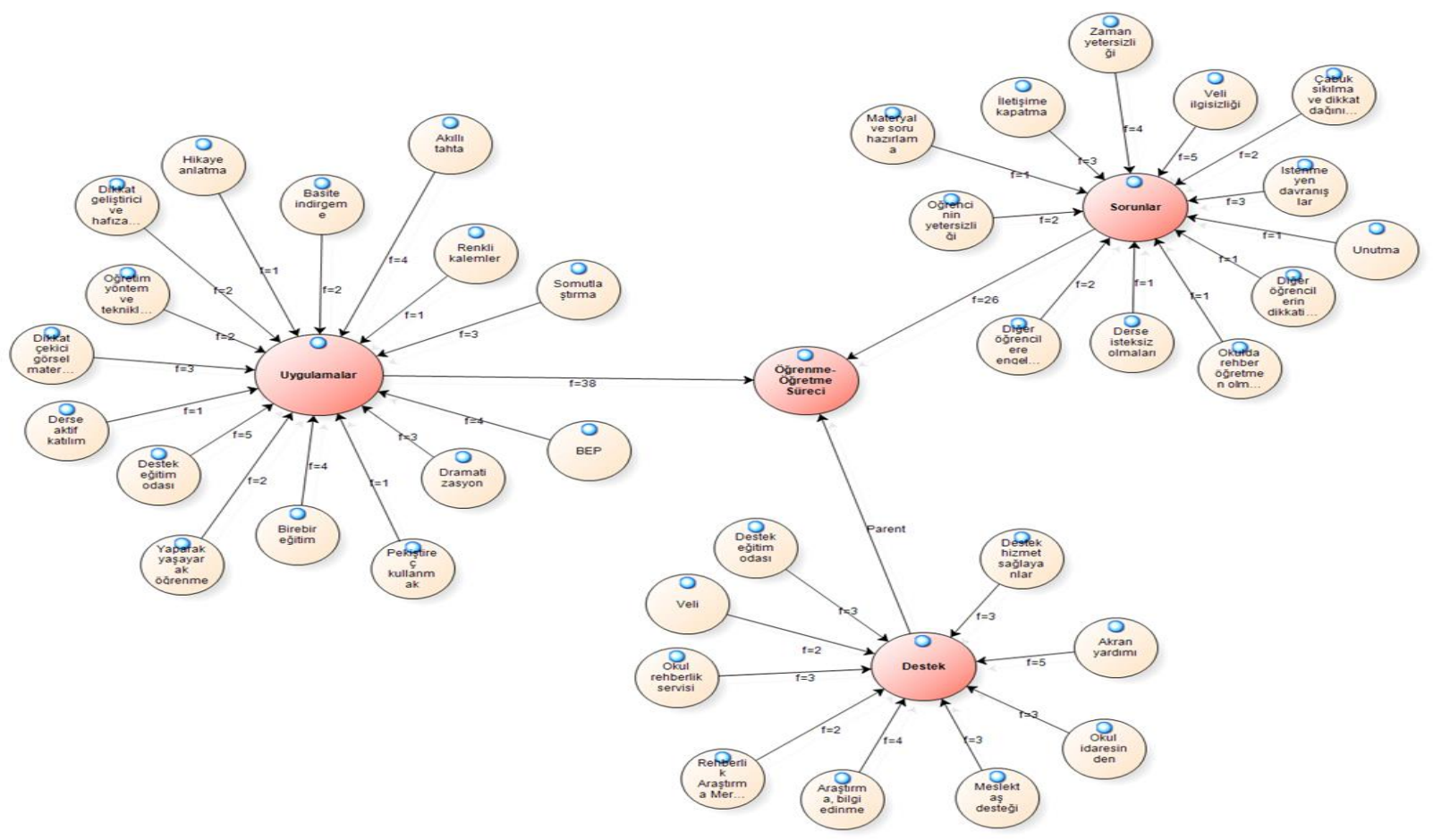

Şekil 3. Öğrenme-öğretme sürecinde yapılan uygulamalar, karşılaşılan sorunlar ve alınan destekler

Sınıfında özel gereksinimli öğrencisi bulunan sınıf öğretmenleri öğrenme-öğretme sürecinde öğretimi bu öğrenciler adına bireyselleştirme anlamında bazı uygulamalar yapmak durumundadırlar. Görüşlerini aldığımız sınıf öğretmenlerinin özel gereksinimli öğrencilerin eğitimleri sırasında ne tür uygulamalar yaptıkları Tablo 8'de sunulmuştur.

Tablo 8. Sınıf öğretmenlerinin öğrenme öğretme sürecinde gerçekleştirdikleri uygulamalar

\begin{tabular}{|c|c|c|}
\hline $\begin{array}{l}\text { Öğrenme-Öğretme Sürecinde Özel Gereksinimli } \\
\text { Öğrenciler İçin Yapılan Uygulamalar }\end{array}$ & Öğretmenler & Frekans (f) \\
\hline Ak1llı tahtadan uygulamalar yapmak & Ö2, Ö5, Ö7, Ö8 & 4 \\
\hline Anlatılanları basite indirgeyerek anlatma & Ö1, Ö10 & 2 \\
\hline BEP doğrultusunda etkinlikler düzenlemek & Ö2, Ö7, Ö8, Ö9 & 4 \\
\hline Çocukla birebir eğitim yapmak & Ö1, Ö4, Ö8, Ö10 & 4 \\
\hline $\begin{array}{l}\text { Destek eğitim odasında yapılan çalışmalardan } \\
\text { yararlanmak }\end{array}$ & Ö1, Ö2, Ö3, Ö5, Ö6 & 5 \\
\hline Dikkat çekici görsel materyaller kullanmak & Ö6, Ö8, Ö9 & 3 \\
\hline $\begin{array}{l}\text { Dikkat geliştirici ve hafiza güçlendirici çalışmalar } \\
\text { yapmak }\end{array}$ & Ö7, Ö8 & 2 \\
\hline Dramatizasyon (oyunlaştırma) & Ö7, Ö8, Ö9 & 3 \\
\hline
\end{tabular}




\begin{tabular}{lll}
\hline Hikâye anlatma & Ö1 & 1 \\
\hline Öğretim yöntem ve tekniklerinde değişiklik yapmak & Ö1, Ö4 & 2 \\
\hline Pekiştireç kullanmak & Ö3 & 1 \\
\hline Renkli kalemler & Ö8 & 1 \\
\hline Somutlaştırma & Ö6, Ö7, Ö9 & 3 \\
\hline Yapabildiği konularda derse aktif katılımını sağlamak & Ö4 & 1 \\
\hline $\begin{array}{l}\text { Yaparak yaşayarak öğrenmeleri için gerekli ortamları } \\
\text { hazırlamak }\end{array}$ & Ö1, Ö5 & 2 \\
\hline
\end{tabular}

Sınıf öğretmenlerinin öğrenme öğretme sürecinde özel gereksinimli öğrenciler için hangi uygulamaları yaptığıyla ilgili bulgular tabloda sunulmuştur. Bu bulgular incelendiğinde, sınıf öğretmenlerinin öğrenme öğretme sürecinde farklı uygulamalara yer verdikleri görülmektedir. Sınıf öğretmenlerinin bu konuda en fazla vurguladıkları nokta destek eğitim odası doğrultusunda yapılan uygulamalardır. Bu uygulamayı, çocukla birebir eğitim yapmak, hazırlanan bireyselleştirilmiş eğitim planı doğrultusunda çalışmalar yapmak ve akıllı tahtadan uygulamalar yapmak takip etmektedir. Daha sonra sırasıyla dikkat çekici görsel materyaller kullanmak, oyunlaştırma yapmak ve anlatılanları somut bir şekilde sunmak öğrenme-öğretme sürecinde sınıf öğretmenleri tarafindan sıklıkla kullanılan uygulamalardır. Öğrenme öğretme sürecinde yaparak yaşayarak öğrenmeleri için gerekli ortamları hazırlamak, yapabildiği konularda derse aktif katılımını sağlamak, hikâye anlatma ve renkli kalemler kullanmak ise öğretmenler tarafından en az kullanılan uygulamalar olarak sayılabilir. Ayrıca sınıf ögretmenlerine bu uygulamaları belirlerken nelere dikkat ettiniz sorusuna öğretmenlerin tamamı öğrencilerin ilgilerine, ihtiyaçlarına ve seviyelerine dikkat ettiklerini belirtmiştir. Bu konuyu Ö1 şu şekilde ifade etmektedir: "Uygulama çocuğun özel gereksinimlerine göre oluyor. Zihinsel veya bedensel gereksinim ne ise ona göre ögretim yöntem ve tekniklerinde değişiklik yapıyorum. Uygulama alanı çok örneği olan bir konu. Yaparak yaşayarak ögrrenmeleri için sinıfta deneyler yapıyoruz. Akademik becerileri için doğrudan anlatım yapıyorum". Sınıf öğretmenlerinin öğrenme öğretme sürecinde yaptıkları uygulamalarda BEP doğrultusunda çalışmalar yapıldığını Ö2 şöyle dile getirmektedir: “...yapabilecekleri doğrultusunda BEP hazırlanıyor. Daha sonra BEP doğrultusunda etkinlikler düzenliyoruz. Sinıfla birlikte yapabileceğimiz etkinliklerin dışındakileri sinıftan ayrı yapıyoruz. Destek eğitim odası doğrultusunda etkinlikler yapıyoruz. Akıllı tahtadan uygulamalar yapıyoruz”. Görüşlerini aldığımız sınıf öğretmenleri öğrenme öğretme sürecinde özel gereksinimli öğrenciler için sıklıkla dramatizasyon (oyunlaştırma) yöntemini kullandıklarını ifade etmektedir. Bu konuda Ö9: “ ...bütün ögretim çalışmalarını oyun üzerinden yapıyorum. Sürekli oyun ve dikkatini çekecek materyallerle eğitimi yapılandırlyorum. Bir kazanımla ilgili üç dört etkinlik yapmaya çalışıyorum".

Özel gereksinimli öğrenciler öğrenme ve davranış anlamında normal gelişim gösteren akranlarından oldukça farklılıklar gösterebilmektedir. Bunu öğrenme-öğretme sürecinde düşündüğümüzde sınıf öğretmenleri yaptıkları uygulamalarda çeşitli zorluklarla karşılaşabilmektedir. Sınıf öğretmenlerinin öğrenme öğretme sürecinde yapmış oldukları uygulamalarda ne tür zorluklarla karşılaştıkları Tablo 9'da sunulmuştur.

Tablo 9. Öğrenme-öğretme sürecinde yapılan uygulamalarda karşılaşılan sorunlar

\begin{tabular}{lll}
\hline Uygulamalarda & Öğretmenler & Frekans (f) \\
\hline Varşılaşılan Sorunlar & Ö1, Ö2, Ö6, Ö9, Ö10 & 5 \\
\hline Zaman yetersizliği & Ö1, Ö7, Ö8, Ö9 & 4 \\
\hline İstenmeyen davranışlar & Ö3, Ö5, Ö9 & 3 \\
\hline
\end{tabular}




\begin{tabular}{lll}
$\begin{array}{l}\text { Öğrencilerin kendilerini iletişime } \\
\text { kapatmaları }\end{array}$ & Ö1, Ö3, Ö9 & 3 \\
\hline Çabuk sıkılma ve dikkat dağınıklı̆̆1 & Ö3, Ö5 & 2 \\
\hline Özel gereksinimli öğrencinin yetersizliği & $\ddot{O} 1$, Ö9 & 2 \\
\hline Diğer öğrencilere engel olması & $\ddot{O} 3$, Ö9 & 2 \\
\hline Diğer öğrencilerin dikkatinin dağılmas1 & Ö1 & 1 \\
\hline Derse isteksiz olmaları & Ö1 & 1 \\
\hline Materyal ve soru hazırlama & Ö10 & 1 \\
\hline Okulda rehber öğretmen olmamas1 & Ö6 & 1 \\
\hline Öğrendiklerini çabuk unutma & Ö2 & 1 \\
\hline
\end{tabular}

Öğrenme-öğretme sürecinde gerçekleştirilen uygulamalarda karşılaşılan güçlükler tablosu incelendiğinde, sınıf öğretmenlerinin özel gereksinimli öğrencilerle gerçekleştirmiş oldukları uygulamalarda çeşitli zorluklarla karşılaştıkları görülmektedir. Sınıf öğretmenlerinin bu uygulamalarda karşılaşılan zorluklardan üzerinde en fazla görüş belirttikleri sorun veli ilgisizliğidir. Görüşlerine başvurduğumuz sınıf öğretmenlerinin yarısı velilerin ilgisiz olduğunu ve süreçte herhangi bir destekte bulunmadıklarını ifade etmiştir. $\mathrm{Bu}$ sorunu sırasıyla zaman yetersizliği, öğrencilerin kendilerini iletişime kapatmaları, çabuk sıkılma ve dikkat dağınıklığı, özel gereksinimli öğrencinin yetersizliği ve diğer öğrencilere engel olması sorunları takip etmektedir. Derse isteksiz olmalar, materyal ve soru hazırlama, okulda rehber öğretmen olmaması ve öğrenilenlerin çabuk unutulması sorunları ise en az vurgulanan sorunlar arasındadır. Sadece bir öğretmen bu uygulamaları gerçekleştirirken herhangi bir sıkıntı yaşamadığını belirtmiştir. “...pek fazla sorunla karşılaşmıyorum” (Ö4).Diğer bütün öğretmenler bu uygulamaları gerçekleştirirken sorun yaşamıştır. Ö1 bu uygulamaları gerçekleştirirken karşılaştığı sorunları şu şekilde ifade etmektedir: "Öğrencilerim akademik anlamda geride oldukları için onlarla çok fazla birebir eğitim yapıyorum. Bu noktada bir ögrrencimle çalışırken, diğer ögrrencilerimin derse olan ilgisi azaliyor ve başka şeylerle uğraşmak istiyorlar. Öğrencilerimin kendilerini kitlemesi ve asla ders yapmak istememeleri de karşılaş̧tı̆̆ım sorunlar arasındadır”. Bu öğrencilerin sinıfta istenmeyen davranışlara sebep olduğunu ifade eden bir diğer öğretmen Ö3 ise bu durumu şöyle ifade etmektedir: "Sınıf içinde çok dikkati dă̆ınıklığına sebep oluyor. Diğer öğrencilerin ögrenmesine engel oluyor. Dikkati üzerine çekmek istiyor. Çok fazla ilgi istiyor. Çok fazla eleştiri kabul etmiyor. Eleştirdiğimizde kendini kitliyor. Adamı çok iyi kullanıyor".

Sınıf öğretmenleri özel gereksinimli öğrencilerin eğitimlerinde uygulamış oldukları uygulamalarda bulgularda verildiği gibi çeşitli sorunlarla karşılaşmaktadır. Öğretmenlerin bu sorunlarla baş edebilmeleri ve sınıfta istenmeyen davranışların önüne geçilmesi adına desteğe ihtiyaç duydukları açıktır. Son olarak sınıf öğretmenlerinin özel gereksinimli öğrencilerin eğitimlerinde karşılaştıkları sorunları gidermek için ne tür destek aldıklarıyla ilgili görüşleri alınmıştır.

Tablo 10. Sinıf öğretmenlerinin öğrenme öğretme sürecinde aldığı destekler

\begin{tabular}{lll}
\hline \multirow{2}{*}{ Destek Türleri } & \multicolumn{2}{l}{$\begin{array}{l}\text { Özel gereksinimli öğrencilerin öğrenme-öğretme sürecinde } \\
\text { karşlaştıkları sorunları gidermek için ne tür destek alıyorsunuz? }\end{array}$} \\
\cline { 2 - 3 } & Öğretmenler & Frekans (f) \\
\hline Akran yardımı & Ö3, Ö5, Ö6, Ö7, Ö9, & 5 \\
\hline Araştırma, bilgi edinme & Ö2, Ö4, Ö8, Ö10 & 4 \\
\hline Destek eğitim odas1 & Ö1, Ö4, Ö5 & 3 \\
\hline
\end{tabular}




\begin{tabular}{lll}
\hline Destek hizmet sağlayanlar & Ö1, Ö4, Ö5, & 3 \\
\hline Meslektaş desteği & Ö1, Ö4, Ö5 & 3 \\
\hline Okul idaresinden & Ö1, Ö2, Ö9, & 3 \\
\hline Okul rehberlik servisi & Ö3, Ö5, Ö7, & 3 \\
\hline $\begin{array}{l}\text { Rehberlik Araştırma Merkezi } \\
\text { (RAM) }\end{array}$ & Ö3, Ö9, & 2 \\
\hline Veli & Ö5, Ö8, & 2 \\
\hline
\end{tabular}

Sınıf öğretmenlerinin özel gereksinimli öğrenciler için yapmış oldukları uygulamalarda karşılaştıkları sorunları gidermek için almış oldukları destekler tabloda sunulmuştur. Bulgular incelendiğinde, sınıf öğretmenleri bu sorunların etkilerini azaltmak anlamında en fazla kullandıkları destek türü akran desteği olmuştur. Akran desteğini, öğretmenin kendi çabalarıyla araştırma ve bilgi edinmesi takip etmiştir. Bu destek türlerinden sonra üzerine görüş bildirilen diğer destekler ise; destek eğitim odası, destek hizmeti sağlayanlar, meslektaş desteği ve okul idaresinden alınan destekler şeklinde sıralanmaktadır. Sınıf öğretmenleri bu süreçte en az desteği de velilerden almışlardır. Bu süreçte veli desteğinin önemine değinen Ö3 bu durumu şöyle ifade etmektedir: “...veli desteği alıyorum. Veli olmadan hiçbir şey yapamıyorum. Çoğunlukla veliden destek alıyorum". Bu sorunların giderilmesi bakımından alınan destekler arasında destek eğitim odasından söz edilmektedir. Bu konuyla ilgili olarak Ö6 destek eğitim odasından yararlandıklarını ancak destek eğitim odasıyla ilgili olumsuzlukları şu şekilde ifade etmiştir: “...destek ĕgitim odasından yararlanıyoruz. Ancak okulumuzda destek eğitim verebileceğimiz bir oda yok, boş bulduğumuz yerleri kullanıyoruz. Dolayısıyla kullanabileceğimiz araçgereç vs. de yok. Ö̆gretmenin kendi çabalarlyla bir şeyler yapması gerekiyor".

\section{TARTIŞMA ve SONUÇ}

$\mathrm{Bu}$ araştırmada sınıf öğretmenlerinin özel gereksinimli öğrencilere yönelik öğrenme-öğretme sürecinde yapmış oldukları uygulamalar ve bu uygulamalarda ne tür zorluklarla karşılaştıklarıyla ilgili görüşleri belirlenmiştir. Öncelikle sınıf öğretmenlerinin özel gereksinimli öğrencilere yönelik eğitim alıp almadıkları sorgulanmış ve öğretmenlerin özel gereksinimli öğrencilere yönelik yeterlilikleri belirlenmiştir. İkinci olarak, özel gereksinimli öğrencilerin özelliklerinin neler olduğu, bu öğrencileri belirlerken nelerden yararlanıldığı, bu süreçte aileyle iletişimin ne düzeyde olduğu ve bu öğrencilerin sosyal ortamlarda desteklenmesi ve akran kabulü için ne tür çalışmalar yapıldığ 1 belirlenmiştir. Son olarak, sınıf öğretmenlerinin öğrenme-öğretme sürecinde özel gereksinimli öğrencilere yönelik ne tür uygulamalar yaptıkları, bu uygulamalarda hangi sorunlarla karşılaştıkları ve bu sorunlarla baş edebilmek için ne tür destek aldıkları öğretmen görüşleri doğrultusunda belirlenmiştir.

Araştırma bulguları doğrultusunda, sınıf öğretmenlerinin özel gereksinimli öğrencilere yönelik eğitim durumlarının yetersiz olduğu sonucuna ulaşılmıştır. Öğretmenler üniversitede özel gereksinimli öğrencilere yönelik herhangi bir eğitim almadıklarını alanlar ise bu eğitimlerin ihtiyacı karşılamaktan uzak olduğunu belirtmiş̦tir. Ayrıca sınıf öğretmenlerinin özel gereksinimli öğrencilere yönelik hizmet içi eğitim aldıkları ancak bu eğitimlerin göstermelik yapıldığı tespit edilmiştir. Dolayısıyla sınıf öğretmenlerinin özel gereksinimli öğrencilere yönelik eğitim durumları yeterli değildir. Bu bilgiler neticesinde sınıf öğretmenleri özel gereksinimli öğrencilere yönelik yeterli eğitim alamamakta ve kendilerini bu konuda yetersiz görmektedirler. Bu sonuca benzer bulgulara, Babaoğlan \& Yılmaz (2010)'un yapmış olduğu çalışmada, Demir \& Açar (2011) tarafından yapılan çalışmada da yer verilmiştir. (Altun \& Gülben, 2009) tarafından okul öncesi öğretmenlerinin görüşleri alınarak yapılan araştırmada ise öğretmenlerin özel gereksinimli öğrencilerin eğitimleri konusunda yeterli bilgiye sahip olmadıkları ifade edilmiştir.

İkinci olarak özel gereksinimli öğrenciler hangi özelliklere sahip, öğretmenler bu öğrencileri belirlemede ne tür yöntemler kullanmaktadır, aileyle iletişim ve özel gereksinimli öğrencilerin sosyal ortamlarda desteklenmesi ve akran kabulü için ne tür çalışmalar yapıldığı üzerinde durulmuştur. Araştırma bulguları incelendiğinde, sınıf öğretmenlerinin gözüyle özel gereksinimli öğrencilerin özellikleri belirlenmiştir. Sınıf öğretmenleri özel gereksinimli öğrencilerin geç ve güç öğrendiğini, 
akranlarına göre akademik başarılarının düşük olduğu, okumakta güçlük çektiklerini, yazmakta ve matematik becerilerinde zorlandıklarını, algılamada güçlük yaşadıklarını, iletişim becerilerinin düşük olduğunu, özgüvenlerinin düşük olduğu ve çabuk yorulup bıktıkları üzerinde durmuştur. Benzer bulgulara (Altun \& Uzuner, 2016) tarafindan özel öğrenme güçlüğü olan öğrencilerin eğitimleri üzerine yapılan araştırmada da rastlanmıştır.

Öğrenme öğretme sürecinde öğretimin bireyselleştirilmesi adına bu öğrencilerin tespitinin önemli olduğu söylenebilir. Bu süreci başlatan kişinin sınıf öğretmeni olduğunu düşündüğümüzde sınıf öğretmenlerinin bu öğrencilerin tespit edilmesinde nelere dikkat ettiği önem kazanmaktadır. $\mathrm{Bu}$ öğrencileri tespit etmek için öğretmenler, gözlemlerinden, öğrencinin akademik başarısından, öğrencinin ailesi ve rehber öğretmenle görüşmekten, çeşitli testlerden, öğrencinin algılama düzeyi ve istenmeyen davranışlarından ve arkadaşlarıyla karşılaştırmaktan yararlanmaktadır. Altun \& Gülben (2009) yaptıkları araştırmada okul öncesi öğretmenlerin özel gereksinimli öğrencilerin hangi akademik alanda eksiklik yaşadığını gözlem yoluyla tespit ettiklerini ifade etmektedir.

Ayrıca sınıf öğretmenleri özel gereksinimli öğrencilerin sosyal ortamlarda desteklenmesi ve akran kabulü için şu çalışmaları yapmaktadır: Öğrencinin yapabildikleri üzerinden öğrenciye başarı duygusunu tattırmak, öğrenciye yapabileceği sorumluluklar vermek, akranlarına öğrencinin durumunu anlatmak, akranlarıyla birlikte oynayabileceği oyunlar düzenlemek, öğrenciyi cesaretlendirmek ve diğer öğrencilerden ayırmamak son olarak grup çalışmaları yapmak. Öğretmenler öğrencilerin sadece akademik başarılarını düşünmemeli aynı zamanda özel gereksinimli öğrencilerin sosyal ortamlarda desteklenmesi ve akranları tarafindan kabul edilmesi için çaba harcamalıdır. Bunu gerçekleştirebilmek için öğrencinin okulda ve sınıfta başarılı olabileceği farklı etkinliklere ve alanlara onları yönlendirmek gerekmektedir (Olçay-Gül \& Vuran, 2015). Aynı zamanda bu öğrencilerin akranları tarafından kabul edilmesi, özel gereksinimli öğrencilerin eğitimleri için önemli olduğu söylenebilir. Sadioğlu ve diğerleri (2012) tarafından yapılan araştırmada özel gereksinimli öğrencilerin akranları tarafından kabul edilmesi için; normal gelişim gösteren öğrenciyi bilgilendirme, sosyal etkileşimi sağlamaya yönelik çalışmalar vb. faaliyetler yapıldığı sonucuna ulaşılmıștır. Ancak sınıf öğretmenleri tarafindan özel gereksinimli öğrencilere yönelik kaynaştırmaya hazırlık etkinlikleri ve akran destekli öğretimin yapılmamış olması bu öğrencilerin akran kabulünü etkilemektedir. Sınıfında özel gereksinimli öğrenci bulunan öğretmenler, öğrenme-öğretme sürecinde kaynaştırma uygulamalarının etkili olması ve akran kabulü için kaynaştırmaya hazırlık etkinlikleri ve akran öğretiminden faydalanabilir. Özel gereksinimli öğrencilerin öğrenme-öğretme sürecinde başarılı bir şekilde eğitim alabilmeleri için sağlanması gereken koşullar bulunmaktadır. Bu koşullar Smith ve diğerleri (2006) tarafından programların öğrenci gereksinimlerine göre karşılanması yahut var olan programların öğrenci ihtiyaçlarına uyarlanması, öğrenme-öğretme sürecinde kullanılan yöntem ve tekniklerin bu öğrencilere göre uyarlanması, başarılı bir sınıf yönetiminin yanında gerekli destek hizmetlerinin sağlanması olarak sıralanmıştır. Bu koşulların sağlanmasıyla beraber özel gereksinimli öğrencilerin sosyalleşmesi ve akran kabulü artırılabilir.

Araştırmanın bir diğer sonucu ise öğretmenlerin özel gereksinimli öğrencilerin ailelerini öğrencilerin hangi alanlarda eksiklik yaşadığı yönünde bilgilendirdikleri ancak ilk etapta velilerin duruma tepki gösterdiği sonucudur. Bu süreçle ilgili olarak öğretmen veli arasındaki işbirliği kısmen yapılabilmiştir. Ayrıca bazı velilerin durumu kabul edip çocukları için her şeyi yaptığı bazılarının ise olumsuz düşüncede olduğu sonucuna ulaşılmıştır. Velilerin çocuklarının durumlarını kabullenmekte sorunlar yaşadıkları Sadioğlu ve diğerleri (2012) tarafından da desteklenmektedir. Altun \& Gülben (2009) tarafından yapılan çalışmada da velilerin bazılarının bilinçli olmalarına rağmen büyük bir kısmının bilinçsiz oldukları üzerine görüş bildirilmiştir.

Sınıfında özel gereksinimli öğrenci bulunan sınıf öğretmenlerinin öğrenme-öğretme sürecinde öğrenciler için farklı uygulamalar düzenlediği sonucuna ulaşılmıştır. Sınıf öğretmenlerinin etkili ve verimli bir öğrenme-öğretme süreci oluşturmak için; özel gereksinimli öğrenci için akıllı tahtadan uygulamalar yaptığı, destek eğitim odasında yapılan çalışmalara paralel etkinlikler düzenlediği, hazırlanan BEP doğrultusunda etkinlikler düzenlediği, birebir eğitim yaptığı, dikkat çekici görsel materyaller kullandığı, derslerde dramatizasyon (oyunlaştırma) tekniğinden sıkça yararlandıkları ve somutlaştırma yaptıkları sonucuna ulaşılmıştır. Sadioğlu (2011)'nun yapmış olduğu araştırmada, öğretmenlerin bu süreçte, farklı materyal kullanma, ödev verme daha basit etkinlikler ve araştırmalar yaptırma gibi öğretimsel uyarlamalar yaptıkları sonucuna ulaşılmıştır. Öğrenme-öğretme sürecinde, öğrenme süreçleri ve ortamları ile öğretim materyalleri ve etkinlikleri özel gereksinimli öğrencilerin 
gereksinimlerine, ilgi ve ihtiyaçlarına göre düzenlenmeli bunun için çeşitli uyarlamalara gidilmelidir (Olçay-Gül, 2014; Shaw, 2011). Araştırmada ulaştığımız sonuçlarla yapılan çalışmalardaki sonuçlar benzerlik göstermektedir. Sınıf ögretmenleri öğrenme-öğretme sürecini özel gereksinimli öğrenciler için uygun hale getirmiştir. Saraç \& Çolak (2012) tarafından yapılan araştırmada, öğretmenlerin özel gereksinimli öğrenciler için herhangi bir öğretimsel düzenleme yapmadığı bu konuda sadece konuları basitleştirmekle yetindikleri ifade edilmiştir.

Öğrenme-öğretme sürecinde yapılan uygulamalarda sınıf öğretmenlerinin bazı sorunlarla karşılaştıkları sonucuna ulaşılmıştır. Öğretmenler bu sorunları: Velinin ilgisiz olması, zaman yetersizliği, istenmeyen davranışlar, öğrencilerin kendilerini iletişime kapatmaları, çabuk sıkılma ve dikkat dağınıklığı, özel gereksinimli öğrencinin yetersizliği ve diğer öğrencilerin öğrenmesine engel olması şeklinde sıralamışlardır. Altun \& Gülben (2009) yaptıkları çalışmada uygulamalarda karşılaştıkları güçlükleri; veli ilgisizliği, istenmeyen davranışlar ve zaman yetersizliği olarak sıralamıştır. Ayrıca Saraç \& Çolak (2012) yapmış olduğu araştırmada sınıf öğretmenlerinin öğrenmeöğretme sürecinde özel gereksinimli öğrencilere vakit ayıramadığı, öğrencilerin dikkatinin çabuk dağıldığı ve problem davranışları yüzünden sınıfın düzenini sağlayamadığı vb. görüşlere yer vermiştir. Yabanc1 literatür incelendiğinde öğretmenlerin öğrenme-öğretme sürecinde benzer sorunlarla karşılaştıkları görülmektedir. Yapılan çalışmalarda, öğretmenlerin kaynaştırma ve özel eğitim hususunda bilgi eksikliği yaşadığı ve yeterli deneyime sahip olmadıkları (Berry, 2011), öğrenmeöğretme sürecinde özel gereksinimli öğrencilere yeterli zaman ayıramadıkları (Blecker ve Boakes, 2010; Horne ve Timmons, 2009), öğretimsel uyarlama yapamadıkları (Lalvani, 2012), öğrenmeöğretme sürecinde materyal eksikliği yaşadıkları ve fiziki ortamların yetersiz olduğu (Balo, 2015; Shevlin, Winter ve Flynn, 2013) gibi sorunlarla karşılaşılmıştır.

Son olarak, öğretmenlerin öğrenme-öğretme sürecinde karşılaşmış oldukları bu sorunları gidermek için destek aldıkları sonucuna ulaşılmıştır. Sınıf öğretmenlerinin bu süreçte aldığı destekler; akran yardımı, öğretmenin kendi çabalarıyla araştırma yapması ve bilgi edinmesi, destek eğitim odası, destek hizmeti sağlayanlar, meslektaş desteği, okul idaresi, okul rehberlik servisi, RAM ve veli olarak sıralanmaktadır. Sadioğlu ve diğerleri (2012) tarafindan yapılan araştırmada da sınıf öğretmenlerinin bu konuda meslektaşlarından destek aldıkları ancak okul yönetimi ve rehber ögretmenden gerekli desteği alamadıkları belirtilmiştir. Saraç \& Çolak (2012)'ın yapmış oldukları çalışmada öğretmenlerin bu süreçte okul rehber öğretmeninden, okul müdürü ve diğer öğretmenlerden destek aldığ 1 ifade edilmiştir. Yapılan bir araştırmada öğretmenlerin bakanlıktan, yasalardan ve ilgili birimlerden yeterince destek ve danışmanlık alamamaları nedeniyle özel gereksinimli öğrencilerin eğitimlerinde sorunlar yaşadıkları sonucuna ulaşılmıştır (Slavica, 2010). Yapılan bir diğer çalışmada ise ilgililerin (okul yöneticisi, öğretmen vs.) yönetmelikler tarafindan yönlendirilmemeleri, yasa ve yönetmelikler oluşturulurken okulların mevcut durumlarının dikkate alınmaması ve konuyla ilgili pilot uygulamaların yapılmaması özel gereksinimli öğrencilerin eğitimlerinde ortaya çıkan sorunların nedeni olarak gösterilmektedir (Thorpe ve Azam, 2010).

Sonuç olarak sınıf öğretmenlerinin özel gereksinimli öğrencilere yönelik üniversitede aldıkları eğitimin yetersiz olduğu ve hizmet içi eğitimlerin de çeşitli nedenlerden bu yetersizliği gideremediği, dolayısıyla kendilerini bu konuda yetersiz hissettikleri belirtilmiştir. Ayrıca sınıf öğretmenleri sınıfta bu öğrencileri tespit edebildikleri, aileleriyle gerekli iletişimi kurduğu ve bu çocukların sosyal ortamlarda desteklenmesi ve akranları tarafından kabulü için çalışmalar yaptığı tespit edilmiştir. Bununla birlikte sınıf öğretmenlerinin öğrenme-öğretme sürecinde öğretimin bireyselleştirilmesi anlamında öğretim sürecinde bir takım uygulamalar yaptıkları, uygulamalarda bazı sorunlarla karşılaştığ 1 ve bu sorunların üstesinden gelebilmek için destek aldığı da ifade edilmiştir. Araştırmada ulaşılan bu sonuçlar doğrultusunda şu öneriler getirilebilir:

1. Sınıf öğretmenlerine, velilere ve ilgililere özel gereksinimli öğrenciyle ilgili eğitimler düzenlenebilir.

2. Sınıf öğretmenlerinin lisans eğitiminde özel gereksinimli öğrencilere yönelik aldığı derslerin içeriğinde düzenlemeler yapılabilir ayrıca teoriden ziyade uygulamaya yönelik çalışmalar yapılabilir.

3. Özel gereksinimli öğrencilerin eğitimlerinin bir plan program çerçevesinde yapılabilmesi için bu öğrencilerin belirlenmesi önemli görülmektedir. Sınıf öğretmenlerine bu öğrencileri belirleyebilmek 
adına yetersizlik türleriyle ilgili ayrıntılı bilgi verilebilir. Yetersizlik türlerine ait belirleyici özellikler broşür halinde öğretmenlere verilebilir.

4. Özel gereksinimli öğrencilerin sosyal ortamlarda desteklenmesi ve akranları tarafından kabul edilmesi için ilgililerin (sınıf öğretmeni, okul rehber öğretmeni, idare, veli vs.) işbirliği içerisinde çalışması sağlanabilir.

5. Özel gereksinimli öğrencilerin öğrenme-öğretme sürecinden etkili ve verimli bir şekilde faydalanabilmeleri için yapılan uygulamalar öğrencinin ilgi, ihtiyaç ve seviyesine uygun olarak düzenlenebilir.

6. Öğrenme-öğretme sürecinde karşılaşılan sorunlarla baş edebilmek için sınıf öğretmenine gerekli desteğin verilmesi sağlanabilir. Kurumlar arasında işbirliği önemli görülebilir.

7. Özel gereksinimli öğrenci bulunan tüm ilkokullarda rehber öğretmen olması sağlanabilir.

8. Destek eğitim odasının öğrenme-öğretme sürecini destekleyecek şekilde düzenlenmesi ve sürdürülmesi sağlanabilir. Ayrıca okullarda, destek eğitim odaları için ayrı bir oda düzenlenebilir, gerekli donanım ve araç-gereç sağlanabilir.

\section{KAYNAKÇA}

Akçamete, A. G. (2012). Genel eğitim okullarında özel gereksinimi olan ögrrenciler ve özel eğitim. Ankara: Kök Yayıncilik.

Altun, T., \& Gülben, A. (2009). Okulöncesinde özel gereksinim duyan çocukların eğitimindeki uygulamalar ve karşılaşılan sorunların öğretmen görüşleri açısından değerlendirilmesi. Selçuk Üniversitesi Ahmet Keleşoğlu Eğitim Fakültesi Dergisi, 253-272.

Altun, T., \& Uzuner, F. G. (2016). Sınıf öğretmenlerinin özel öğrenme güçlüğü olan öğrencilerin eğitimine yönelik görüşleri. International Journal of Social Science, 33-49.

Avcıŏlu, H. (2011). Zihin engelliler sınıf öğretmenlerinin bireyselleştirilmiş eğitim programı (bep) hazırlamaya ilişkin görüşleri. Ankara Üniversitesi Eğitim Bilimleri Fakültesi Özel Eğitim Dergisi, 39-53.

Babaoğlan, E., \& Yılmaz, Ş. (2010). Sınıf öğretmenlerinin kaynaştırma eğitimindeki yeterlilikleri. Kastamonu Eğitim Dergisi, 345-354.

Balo, E. D. (2015). İlkokullarda kaynaştırma eğitimi uygulamalarında karşılaşılan sorunlar ve çözüm önerileri (Yayınlanmamış yüksek lisans tezi). Fırat Üniversitesi, Eğitim Bilimleri Enstitüsü, Elazı̆̆.

Batu, S. (2000). Kaynaştırma, destek hizmetler ve kaynaştırmaya hazırlık etkinlikleri. Ankara Üniversitesi Ĕgitim Bilimleri Fakültesi Özel Eğitim Dergisi, 35-47.

Batu, S. (Eds.). (2015). Özel Ĕgitim. Ankara: Pegem Akademi.

Batu, S., \& Kırcaali-İftar, G. (2005). Kaynaştırma. Ankara: Kök Yayıncılık.

Batu, S., Kırcaali-İftar, G., \& Uzuner, Y. (2004). Özel gereksinimli öğrencileri kaynaştırıldığı bir kız meslek lisesindeki öğretmenlerin kaynaştırmaya ilişkin görüşleri. Anakara Üniversitesi Eğitim Bilimleri Fakültesi Dergisi.

Berry, R. A. W. (2011). Voices of experience: General education teachers on teaching students with disabilities. International Journal of Inclusive Education, 15, 627-648.

Blecker, N. ve Boakes, N. (2010). Creating a learning environment for all children: Are teachers ableand willing? International Journal of Inclusive Education, 14(5), 435-447.

Büyüköztürk, Ş. (2017). Bilimsel Araştırma Yöntemleri. Ankara: Pegem Akademi.

Çepni, S. (2012). Araştırma ve Proje Çalış̧malarına Giriş. Trabzon.

Demir, M., \& Açar, S. (2011). Kaynaştırma eğitimi konusunda tecrübeli sınıf öğretmenlerinin görüşleri. Kastamonu Eğitim Dergisi, 719-732.

Diken, İ. (2015). Özel Ĕgitime Gereksinimi Olan Öğrenciler ve Özel Eğitim. Ankara: Pegem Akademi.

Ekiz, D. (2013). Bilimsel Araştırma Yöntemleri. Ankara: Anı Yayıncıllk.

Eripek, S. (2005). Özel Eğitim. Eskişehir: Anadolu Üniversitesi AÖF Yayınları.

Erişkin, A., Kıraç, S., \& Ertuğrul, Y. (2012). Sınıf öğretmenlerinin kaynaştırma uygulamalarına ilişkin görüşlerinin değerlendirilmesi. Milli Eğitim Dergisi, 200-213.

Freeman, S., \& Alkin, M. (2000). Genel eğitim ve özel eğitim ortamlarında zihinsel engelli çocukların akademik ve sosyal başarıları. Remedialand Special Education, 3-18. 
İlgar, Ş. (2017). Öğretmen adaylarının özel gereksinimli öğrencilerle ilgili farkındalığının incelenmesi. Hasan Ali Yücel Eğitim Fakültesi Dergisi, 313-338.

Kargın, T., Güldenoğlu, B., \& Şahin, F. (2010). Genel eğitim sınıflarındaki özel gereksinimli öğrenciler için yapılması gereken uyarlamalara ilişkin sınıf öğretmenlerinin görüşlerinin incelenmesi. Kuram Ve Uygulamada Eğitim Bilimleri.

Kırcaali-İftar, G. (1998). Özel Gereksinimli Bireyler ve Özel Eğitim. Eskişehir: Anadolu Üniversitesi Yayınları.

Lalvani, P. (2012). Privilege, compromise, or social justice: Teachers' conceptualizations of inclusive education. Disability and Society, 28, 14-27.

Olçay-Gül, S., \& Vuran, S. (2015). Normal sınıflara devam eden özel gereksinimli öğrencilerin kaynaştırma uygulamasına iliş̧in görüşleri ve karşılaş̧ıkları sorunlar. Eğitim ve Bilim, 169-195.

Olson, J., \& Platt, J. (2004). Teaching Children and Adolescents With Special Needs. New Jersey: Prentice Hall.

Özokçu, O. (Eds.). (2013). Özel Eğitim. Ankara: Maya Akademi.

Phyllis E. Horne \& Vianne Timmons (2009) Making it work: teachers' perspectives on inclusion, International Journal of Inclusive Education, 13:3, 273-286, DOI:10.1080/13603110701433964

Rosenberg, M., Westling, D., \& McLeskey, J. (2008). Special Education for Today's Teachers: An Introduction. Upper Saddle River: Prentice Hall.

Sadioğlu, Ö. (2011). Sinı Öğretmenlerinin Kaynaştırmaya Illişkin Sorunları, Beklentileri ve Önerilerine Yönelik Nitel Bir Araştırma. Uludağ Üniversitesi Eğitim Bilimleri Enstitüsü: Bursa.

Sadioğlu, Ö., Batu, S., \& Bilgin, A. (2012). Sınıf öğretmenlerinin özel gereksinimli öğrencilerin kaynaştırılmasına ilişkin görüşleri. Uludă̆ Üniversitesi Eğitim Fakültesi Dergisi, 399-432.

Saraç, T., \& Çolak, A. (2012). Kaynaştırma uygulamaları sürecinde ilköğretim sınıf öğretmenlerinin karşılaştıkları sorunlara ilişkin görüş ve önerileri. Mersin Üniversitesi Eğitim Fakültesi Dergisi, 13-28.

Shaw, R. A. (2011). Employing universal design for learning. New Directions for Student Services, 21-33.

Shevlin, M., Winter, E., \& Flynn, P. (2013). Developing inclusive practice: teacher perceptions of opportunities and constraints in there public of Ireland. International Journal of Inclusive Education, 1119-1133.

Slavica, P. (2010). Inclusive education: proclamation so reality (primary school teachers' view). Australian Journal of Teacher Education, 7, 62-69.

Smith, T. E. C., Polloway, E. A., Patton, J. R. ve Dowdy, C. A. (2006). Teaching students with special needs in inclusive settings, (revised IDEA edition). Boston: Allyn \& Bacon.

Smith, T. E., Polloway, E. A., \& Patton, J. R. (2008). Teaching Students With Special Needs in Iclusive Settings. Boston: Merrill Prentice Hall.

Sucuoğlu, B. (2006). Etkili Kaynaştırma Uygulamaları. Ankara: Ekinoks Yayınları.

Sucuoğlu, B., \& Kargın, T. (2006). Kaynaştırma Uygulamaları: Yaklaşımlar, Yöntemler, Teknikler. İstanbul: Morpa Yayınları.

Şahbaz, Ü., \& Kalay, G. (2010). Okulöncesi eğitimi öğretmen adaylarının kaynaştırmaya ilişkin görüşlerinin belirlenmesi. Mehmet Akif Ersoy Üniversitesi Ĕgitim Fakültesi Dergisi, 116-135.

Thorpe, A., ve Azam, A. Q. M. S. (2010).Teachers' perceptions of inclusive education in main stream primary schools in the united kingdom. The International Journal of Interdisciplinary Social Sciences, 5, 163-172.

Yıldırım, A., \& Şimşek, H. (2016). Sosyal Bilimlerde Nitel Araştırma Yöntemleri. Ankara: Seçkin Yayıncılık. 